Molinillo, F., Liébana-Cabanillas, F., Anaya-Sánchez, R., Buhalis, D., 2018, DMO online platforms: image and intention to visit, Tourism Management, Vol.65, pp.116130 http://www.sciencedirect.com/science/article/pii/S026151771730211X

\title{
Applicable
}

\section{DMO ONLINE PLATFORMS: IMAGE AND INTENTION TO VISIT}

\begin{abstract}
The online platforms (i.e., websites and social media) of Destination Management Organizations (DMOs) are among the most useful tools for building and promoting a destination image (DI). However, the associated effects on the DI have not been sufficiently studied and prior research has not assessed the influences of involvement on the DI formation process. The aim of this study is to explore the moderating effects of DMO online platforms on the DI through a conceptual model. The proposed model was empirically verified through an experiment and tested using PLS-SEM method. The findings demonstrate that tourist involvement has a positive impact on cognitive image and affective image, forming the DI as an antecedent of the intention to visit. The results also show that image formation and intention to visit the destination vary depending on the platform used by travelers to access the information.
\end{abstract}

Keywords: Destination image, intention to visit, DMO, website, social media, Millennials.

\section{Introduction}

The strategic use of information and communication technologies (ICTs) by Destination Management Organizations (DMO) has been a relevant topic in tourism research since the 90s (Buhalis, 1993, 1998; Poon, 1993; Sheldon, 1997). The internet has changed dramatically the marketing practices of DMOs (Fesenmaier, Gretzel, Hwang, \& Wang, 2003; Gretzel, 
Yuan, \& Fesenmaier, 2000; Law, Buhalis, \& Cobanoglu, 2014). DMOs have to face the ICT challenges and adapt their strategies (Gretzel, Fesenmaier, Formica, and O’Leary, 2006; Hays, Page, \& Buhalis, 2013). DMOs have to address these strategies in an increasingly competitive global environment with more sophisticated consumers, and with growing needs for greater efficiency and customer satisfaction (Buhalis, 2000; Inversini, Cantoni, \& De Pietro, 2014; Law et al., 2014). DMOs can take advantage of the internet to customize the information they provide and interact directly with tourists (Buhalis \& Law, 2008; Pan \& Fesenmaier, 2006; Pike \& Page, 2014) who, in turn, are increasingly using DMO websites and social media as sources of information (Hays et al., 2013; Law, Qi, \& Buhalis, 2010; Luna-Nevarez \& Hyman, 2012; Mariani, Di Felice, \& Mura, 2016; Woodside, Ramos-Mir, \& Duque, 2011; Xiang \& Gretzel, 2010).

Online information sources have a strong influence on tourist behavior (Buhalis, 2000; Kim \& Fesenmaier, 2008; MacKay \& Vogt, 2012; Tan \& Wu, 2016). Interacting with multimediaenhanced websites and social media allows consumers to "experience" destinations without actually visiting the physical location (Buhalis \& Law, 2008) and leads to the formation of the destination image (DI) (Cho, Wang, \& Fesenmaier, 2002). However, DMOs use of social media is still largely experimental (Hays et al., 2013; Mariani et al., 2016), and its effects on DI have not been sufficiently studied (Kladou \& Mavragani, 2015; Költringer \& Dickinger, 2015; Munar \& Jacobsen, 2014).

The information about a destination that potential visitors process from a variety of sources results in the formation of a DI in their minds (Beerli \& Martín, 2004; Frías, Rodríguez, \& Castañeda, 2008; Gartner, 1994; Jeong, Holland, Jun, \& Gibson, 2012; MacKay \& Fesenmaier, 1997). There are numerous meanings behind the term "destination image” (e.g., 
Frías et al., 2008; Gartner, 1994; Hunt, 1975; Josiassen, Assaf, Woo, \& Kock, 2016; Kim \& Richardson 2003; Lai \& Li, 2016; MacKay \& Fesenmaier 1997). One of the primary definitions considers DI to be "the sum of beliefs, ideas, and impressions that a person has of a destination” (Crompton, 1979, p. 18). From the literature review, Gallarza, Saura and García (2002), suggest that DI is a complex, relative, multiple, and dynamic concept. More recently, Lai \& Li (2016, p. 10) have defined tourist DI as “a voluntary, multisensory, primarily picture-like, qualia-arousing, conscious, and quasi-perceptual mental (i.e., private, non-spatial, and intentional) experience held by tourists about a destination.”

According to Lai and Li (2016), several conceptual DI models have been proposed: the threecontinuum model (Echtner \& Ritchie 1991), the two-dimensional model (Baloglu \& McCleary, 1999), the three-dimensional model (Gartner 1994), the long tail distribution model (Pan \& Li, 2011; Stepchenkova \& Li 2012), and the core-peripheral model (Lai \& Li, 2016) are among the more important approaches to understanding the internal structure of DI. Baloglu and McCleary (1999) present a DI model based on two dimensions (i.e. cognitive image and affective image) that together result in an overall image. Although the number and interpretation of image dimensions may differ between cultures (MacKay \& Fesenmaier, 2000), Baloglu \& McCleary’s model has been validated by a significant number of tourism studies in different cultural environments (e.g., Beerli \& Martín, 2004; Hallmann, Zehrer, \& Müller 2015; Hosany, Ekinci, \& Uysal 2006; Kim \& Richardson 2003; Lin, Morais, Kerstetter, \& Hou, 2007; Mano \& da Costa 2015; San Martín \& Rodríguez del Bosque 2008; Smith, Smith, Li, Pan, Witte, \& Doherty, 2015; Tan \& Wu, 2016). Therefore, this study conceptualizes DI as a two-dimensional model formed by cognitive image and affective image. 
DI is an important aspect of the success of a tourism destination (Tasci \& Gartner, 2007) due to its influence on the selection of a destination (Baloglu \& McCleary, 1999; Beerli \& Martín, 2004; Bigné, Sánchez, \& Sánchez, 2001; Chen \& Tsai, 2007). When a potential visitor develops a positive DI, they will consider this destination in the selection process (Choi, Tkachenko, \& Sil, 2011; Crompton, 1979; Fakeye \& Crompton 1991; Gartner, 1994; Hunt, 1975; Kim \& Stepchenkova, 2015; MacKay \& Fesenmaier 1997). Since people tend to have limited knowledge about destinations they have not yet visited (Chon, 1991; Jeong et al., 2012), they largely depend on the perceived DI based on the information sources they use to help make their selection (Beerli \& Martín, 2004). Destination Management Organizations attempt to build, promote and maintain a DI that encourages visits based on the information distributed through official websites and social media, in addition to traditional media (Gretzel et al., 2000; Gretzel et al., 2006; Hays et al., 2013; Law et al., 2014; Luna-Nevarez \& Hyman, 2012; Mariani et al., 2016). Consequently, it is crucial to understand the DI formation process through DMOs’ official websites and social media, and the subsequent effects on tourists' behavioral intentions, in order to effectively promote a tourism destination globally (Bastida \& Huan, 2014; Jeong et al., 2012; Kock, Josiassen, \& Assaf, 2016; Költringer \& Dickinger 2015; Michaelidou, Siamagka, Moraes, \& Micevski, 2013).

In addition to information sources, personal characteristics influence the perceived DI (Baloglu \& McCleary, 1999; Beerli \& Martín, 2004; Gartner, 1994). Researchers have highlighted “involvement” as one of the most influential characteristics (Frías et al., 2008; Havitz \& Dimanche, 1990; Josiam, Smeaton, \& Clements, 1999; Rodríguez-Molina, FríasJamilena, \& Castañeda-García, 2015). In the context of this study, involvement is defined as the motivational state or interest of an individual induced by a particular stimulus or situation (Frías et al., 2008). Hence, involvement has an impact on information processing and 
influences DI (Lu, Chi, \& Liu, 2015; Prayag \& Ryan, 2012). There are very few studies on the effects of involvement on DI in the context of online information sources. Involvement moderates the DI that tourists perceive through the internet (Frías et al., 2008), as well as through destination websites (Rodríguez-Molina et al., 2015). Prior research however has not assessed the relationship between involvement and the cognitive and affective image dimensions on the DMO website and social media (e.g., Facebook, YouTube, and Instagram).

Empirical research on this topic regarding Millennials (an ideal target group in an online context) is rather scarce. This is a high-value market segment for tourist destinations, as young people often travel for longer periods of time and spend more money than older travelers (Richards, 2016). Researchers have demonstrated that Millennials have different information sources than older generations (Huang \& Petrick, 2010; Li, Li, \& Hudson, 2013), but their findings do not explain the possible moderating effect of online media platforms on Millennials’ perception of DI.

The purpose of this study is to expand knowledge about the perception of online DI and its impact on the intention to visit. The aim of this research is to explore the moderating effects of DMOs’ online platforms (i.e., official websites and social media, including Facebook, YouTube, and Instagram) through a model that links tourist involvement, cognitive image, affective image, overall image, and intention to visit in the context of Millennial leisure travelers. This framework draws on DI theory (Baloglu \& McCleary, 1999; Dichter, 1985; Gartner, 1994; Kim \& Stepchenkova, 2015; Lin et al., 2007), the theory of reasoned action (Fishbein \& Ajzen, 1975), and generational theory on tourism consumer behavior (Li et al., 2013; Mannheim, 1952; Pendergast, 2010). 


\section{Literature review}

\subsection{Millennials}

Generational theory suggests that members of a generation experience the same events at the same chronological age. These experiences impinge upon a similarly 'stratified' consciousness and make members of a generation distinct in their tastes and behavior from members of other generations (Mannheim, 1952). Thus, generational theory is one of the common approaches to researching tourist behavior (Pendergast, 2010). Tourists respond to several generational profiles such as the Silent Generation, Baby Boomers, Generation X, and Generation Y (Li et al., 2013). Generation Y refers to individuals who were born between 1982 and 2002; Millennials (those who born in the period 1985-1999) are the central band of the Y-Generation cohort. Therefore, they are likely to exhibit the traits of that generation in a more convincing way (Pendergast, 2010). They are currently in their young adult phase of life and are expected to become the leaders, managers and consumers of tourism experiences by 2020 (Benckendorff, Moscardo, \& Pendergast, 2010). This cohort has become one of the fastest growing segments of international tourism, accounting for over $23 \%$ of all international travelers in 2015 and spending more than USD 286 billion by 2014 -50\% higher than in 2009 (Richards, 2016). Therefore, this age group is one of the most important segments for the tourism industry.

Millennials are strongly influenced by friends and peers, adept at learning new things, collaborative and interactive, focused on fun, and immersed in the digital culture (Pendergast, 2010). They are connected, have a global perspective and eager to experience the world. These digital natives are the most visually sophisticated and tech-savvy generation (Nadeem, Andreini, Salo, \& Laukkanen, 2015). Young people with more experience using new technologies are more likely to purchase tourism products online seeking instant gratification 
(Escobar-Rodríguez, Grávalos-Gastaminza, \& Pérez-Calañas, 2016). The Internet is essential to Millennials choosing tourist destinations since it allows them to access a large amount of information (Li et al., 2013). They are very active users of social media (Pew Research Center, 2015), where they can create and share content as well as interact with others (Bolton et al., 2013; Nusair, Bilgihan, Okumus, \& Cobanoglu, 2013). These relationships have modified their cognitive and affective perception about the Internet (Immordino-Yang, Christodoulou, \& Singh, 2012).

\subsection{Online destination image and $\mathrm{DMO}$}

For a person that has not yet visited a tourist destination, the DI is formed based on different sources of information (Echtner \& Ritchie, 1991) from mass media providers, intermediaries, visitors, and other agents (Choi, Lehto, \& Morrison, 2007). The emergence of the internet has led to the proliferation of information and content, which affect the formation of the DI (Govers \& Go, 2003). Online information systems have made DI formation a more dynamic process, with greater importance given to the available information, other users' opinions and visual images (Hunter, 2016).

Research focused on the online destination image has studied how users often form an image of the destination based on online sources, taking into account the impact of the available content and information (e.g. Frías et al., 2008; Jeong et al., 2012; Llodrà-Riera, MartínezRuiz, Jiménez-Zarco, \& Izquierdo-Yusta, 2015; Mak, 2017; Rodríguez-Molina et al., 2015). The online image is affected by the phrases used in the search engines, the type of message, shared images, website access, and the types of users that generate eWOM, among other aspects (Avraham, 2015; González-Rodríguez, Martínez-Torres, \& Toral, 2016; Hunter, 2016; Mak, 2017; Pan \& Li, 2011; Rodríguez-Molina et al., 2015). It is therefore important to 
understand the multiple representations of one specific destination that may exist on the Internet (Choi et al., 2007), for example, between different platforms, either controlled by the DMO or other companies or users (Garay-Tamajón \& Cànovez-Valiente, 2017; GonzálezRodríguez et al., 2016; Kladou \& Mavragani, 2015; Stepchenkova \& Zhan, 2013; Tseng, Wu, Morrison, Zhang, \& Chen, 2015; Ye, Zhang, \& Law, 2009). Thus, DMOs need to understand the differences between official travel websites and social media on the DI (Gretzel et al., 2000; Gretzel et al., 2006; Hays et al., 2013; Jeong et al., 2012; Law et al., 2014; LunaNevarez \& Hyman, 2012). However, researchers tend to focus on evaluating the performance of DMO websites in terms of content and accessibility (Jeong et al., 2012; Woodside et al., 2011) or studying how DMOs employ social media to promote and market their destinations (Hays et al., 2013; Mariani et al., 2016).

Researchers have highlighted the main implications of the Internet for DMOs in terms of management and developing marketing strategies (Buhalis, 2000; Fesenmaier et al., 2003; Gretzel et al., 2006). Some authors have developed methods for evaluating the quality and usefulness of websites and comparing the performance of different DMOs (Bastida \& Huan, 2014; Dion \& Woodside, 2010). DMOs use different approaches to target potential visitors through their official websites, ranging from purely informative with simple designs to highly commercial and visually attractive (Luna-Nevarez \& Hyman, 2012). Woodside et al. (2011) find that the usefulness of a tourist destination's website for potential visitors is not substantially correlated to the relative number of tourists (relative to the destination's residential population). Chung, Lee, Lee, and Koo (2015) demonstrate that the quality of the information on DMO websites indirectly affects people's intentions to visit the destination. The positive effect of DMO websites on DI and the intention to visit has even been observed when a website shows cultural values that are inconsistent with the target audience (Tigre 
Moura, Gnoth, \& Deans 2015). The image presented by the content on the DMO’s official website is different than the image presented by other online information sources (tour operators and travel agents' websites, online travel magazines and travel guide websites, online travel communities and online travel “blogs”) (Choi et al., 2007; Költringer \& Dickinger, 2015; Michaelidou et al., 2013). For example, Stepchenkova and Zhan (2013) identify significant differences in image development in Peru depending on whether it is based on photos published by a DMO on its official website or the photos posted by tourists on Flickr. The information offered on the destination's official website affects the formation of cognitive and overall destination images (Jeong et al., 2012).

Regarding social media platforms, the majority of the aforementioned studies have analyzed these platforms from the perspective of User Generated Content (UGC) (Law et al., 2014), but few researchers have focused on the perceived image portrayed through platforms run by the DMOs. Hays et al. (2013) state that the use of social media among top national tourism organizations is still in an experimental stage. For instance, Avraham (2015) shows how DMOs have used social media to allow visitors to share pictures and videos of their country in order to rebuild their DI during times of crisis. Mariani et al. (2016) highlight the role of visual content and the moderate impact of posts on engaging DMO social media users. Thus, in spite of the significant role of DMO online platforms on the image formation process, few researchers have empirically examined the moderating role of DMO websites and social media on DI.

\subsection{The effect of involvement on tourists' destination image formation}

Baloglu and McCleary (1999) have modeled DI based on two dimensions: cognitive image and affective image. The cognitive dimension refers to beliefs or knowledge about a 
destination's attributes whereas the affective dimension refers to feelings toward, or attachment to said destination. The cognitive and affective images a tourist has before visiting a destination is based on information coming from different sources, which the mind processes and organizes in a way that takes on meaning for the individual (Frías et al., 2008).

The effect of information on the DI is influenced by the tourist's involvement (RodríguezMolina et al., 2015), which, in turn, affects the types of resources to be used in communicating the DI (e.g., images) (MacKay \& Fesenmaier, 1997). Zaichkowsky (1985, p. 342) defines involvement as: “A person's perceived relevance of the object based on inherent needs, values, and interests.” Involvement is also described as a psychological state of motivation, arousal, or interest between an individual and tourist destinations (Havitz \& Dimanche, 1990). Involvement is considered a critical psychographic construct of consumer behavior due to its mediation of information processing (Wang \& Fesenmaier, 2003), as well as its influence on the individual's activities and the decisions they make (Josiam et al. 1999). The level of involvement can vary based on the activities, products, and individual characteristics (Prayag \& Ryan, 2012). Accordingly, McGehee, Yoon, and Cárdenas (2003) have demonstrated that tourists' behaviors can differ based on their degree of involvement. The selection of a tourist destination requires a high degree of consumer involvement, as it is a complex project (Stepchenkova \& Li, 2014). The most involved individuals are willing to make more of a cognitive effort in decision-making (Punj \& Moore, 2009) and high levels of involvement have been shown to positively affect cognitive image (Martín-Santana, BeerliPalacio, \& Nazzareno, 2017) and overall image (Lu et al., 2015; Prayag \& Ryan, 2012). Consequently, we propose the following hypotheses:

H1. High levels of involvement have a positive impact on cognitive image. 
H2. High levels of involvement have a positive impact on affective image.

\subsection{The process of destination image formation}

The dimensionality of DI is divided among the existing literature on this subject (Josiassen et al., 2016). This study follows the concepts delineated by Baloglu and McCleary (1999), which presents two sides of the image formation process (i.e., cognitive and affective) leading to the overall image. A significant number of studies have validated this twodimensional conception of DI (e.g., Beerli \& Martín, 2004; Hallmann et al., 2015; Lin et al., 2007; Smith et al., 2015; Tan \& Wu, 2016). “The cognitive component constitutes awareness: what someone knows or thinks they know about a destination. The affective component is based on how one feels about this knowledge” (Konecnik \& Gartner, 2007, p. 403). Within the context of tourism, cognitive image is usually related to the perception of whether a destination has enough available resources to ensure tourists’ comfort and safety (Beerli \& Martín, 2004), or the perception of whether it is more or less friendly, accessible, overcrowded, etc. (Smith et al., 2015). Affective image is related to the emotional perspective, represented by the individual's feelings towards the tourist destination (Beerli \& Martín, 2004). An amalgam of emotional experiences including pleasure and excitement are often evoked by tourist destinations (Walmsley \& Young, 1998). Researchers agree that affective image is a subjective, emotional response to cognitive knowledge regarding a tourist destination (Li, Cheng, Kim, \& Petrick, 2008; Smith et al., 2015). Thus, cognitive image positively influences affective image even before visiting the destination (Kim \& Stepchenkova, 2015; Tan \& Wu, 2016). Accordingly, we have formulated the following hypotheses:

H3. A favorable cognitive image has a positive impact on overall image. 
H4. A favorable cognitive image has a positive impact on affective image.

H5. A favorable affective image has a positive impact on overall image.

\subsection{The effect of overall destination image on intention to visit}

DI is as an important antecedent of tourist behavior (Josiassen et al., 2016; Kim \& Stepchenkova, 2015; Tan \& Wu, 2016). Martín-Santana et al. (2017) point out that overall DI affects tourist behavior in three phases: pre-visit, during a visit, and post-visit. During the pre-visit phase, DI has a significant influence on the potential visitor’s intentions and decisions due to the intangible nature of the destination and their limited knowledge of the location. The decision to visit a destination is a common thread in measuring behavioral intentions (Zhang, Fu, Cai, \& Lu, 2014). Intention to visit is an important outcome variable, as it has a substantial correlation with travel behavior (Noh, 2007). Destinations with a negative image will be eliminated from the tourist's decision-making process (Goodall, 1991), while those with a positive image are more likely to be chosen (Tan \& Wu, 2016). There are indications that non-visitors' future intentions to visit are positively influenced by affective image, cognitive image (Kim \& Stepchenkova, 2015), and overall image (Choi et al., 2011). These findings therefore lead to the following hypothesis:

H6. A favorable overall image has a positive impact on tourists' intentions to visit.

\subsection{The moderating effect of DMO's online platforms}

The information sources used by tourists affect DI (Baloglu and McCleary, 1999). Websites and social media are key sources of information for DI formation. The literature suggests similarities and differences in the perceived DI on the official website and social media sites (Költringer \& Dickinger, 2015; Llodrà-Riera et al., 2015; Stepchenkova \& Zhan, 2013). It is 
important therefore to examine and compare the platform's influence on the DI formation process in order to provide recommendations to DMOs for their online marketing strategies.

The destination's official website serves as a basic tool for providing tourists access to information regarding the destination, thereby forming their first impression of the destination and improving their perceived image with useful and reliable information (Cho \& Sung, 2012; Dion \& Woodside, 2010; Luna-Nevarez \& Hyman, 2012). Researchers have shown the positive effect of DMO websites on DI and intention to visit (Jeong et al., 2012; Tigre Moura et al., 2015). This effect is better when emotional messages are employed on the website and when the tourist does not experience overload (Rodríguez-Molina et al., 2015). In addition to official websites, DMOs use social media to engage with consumers and enhance the positive impact on the DI (Davidson \& Keup, 2014; Hays et al., 2013; Lim, Chung, \& Weaver, 2012). Social media sites are also used by tourists to share experiences and opinions through text, photos and videos (Munar, 2012; Xiang \& Gretzel, 2010). Social media is characterized by bottom-up production and continuous transformation of material, but many DMOs still opt for a top-down approach (Davidson \& Keup, 2014; Mariani et al., 2016). Nevertheless, social media is the richest and most diverse source of online information, while DMO websites provide less online information (Költringer \& Dickinger, 2015). However, the former is still fairly chaotic and difficult to study whereas the latter is structured and more accessible.

Tourists are very familiar with social media sites for travel planning due to their usefulness, ease of use, enjoyment (Ayeh, Au, \& Law, 2013) and trustworthiness (Fotis, Buhalis, \& Rossides, 2012). Social media have a greater impact on DI than DMO websites (Llodrà-Riera et al., 2015). Social media especially focus on cognitive aspects of DI (Kladou \& Mavragani, 
2015; Stepchenkova, Kim, \& Kirilenko, 2015), mostly using photos and videos (Munar \& Jacobsen, 2014), given their greater ability to stimulate the tourist’s senses (Xiong, Hashim, \& Murphy, 2015). In this regard, Mariani et al. (2016) indicate that visual content has a positive impact on tourists’ engagement with DMOs on Facebook.

The platforms used by tourists to collect information about a destination moderate their perceived image of it and, consequently, their intention to visit. The information obtained through social media often has a greater impact on the image than the information obtained from the destination's official website. However, since not enough theoretical evidence has been found to support the corresponding hypotheses, the following exploratory research question should be considered:

RQ: What is the moderating effect of DMO online platforms (i.e., official website, Facebook, YouTube, and Instagram) on the structural relationships between involvement, cognitive image, affective image, overall image, and intention to visit?

\subsection{Conceptual framework}

The research model shown in figure 1 proposes that higher levels of involvement have a positive impact on cognitive image (Hypothesis 1) and affective image (Hypothesis 2); a favorable cognitive image has a positive impact on overall image (Hypothesis 3) and affective image (Hypothesis 4); a favorable affective image has a positive impact on overall image (Hypothesis 5); and a favorable overall image has a positive impact on tourists’ intentions to visit. Finally, the exploratory research question suggests that variances could exist between DMO websites and social media (i.e., Facebook, YouTube, and Instagram) in regard to the regression weights of the hypothesized path analysis model. 


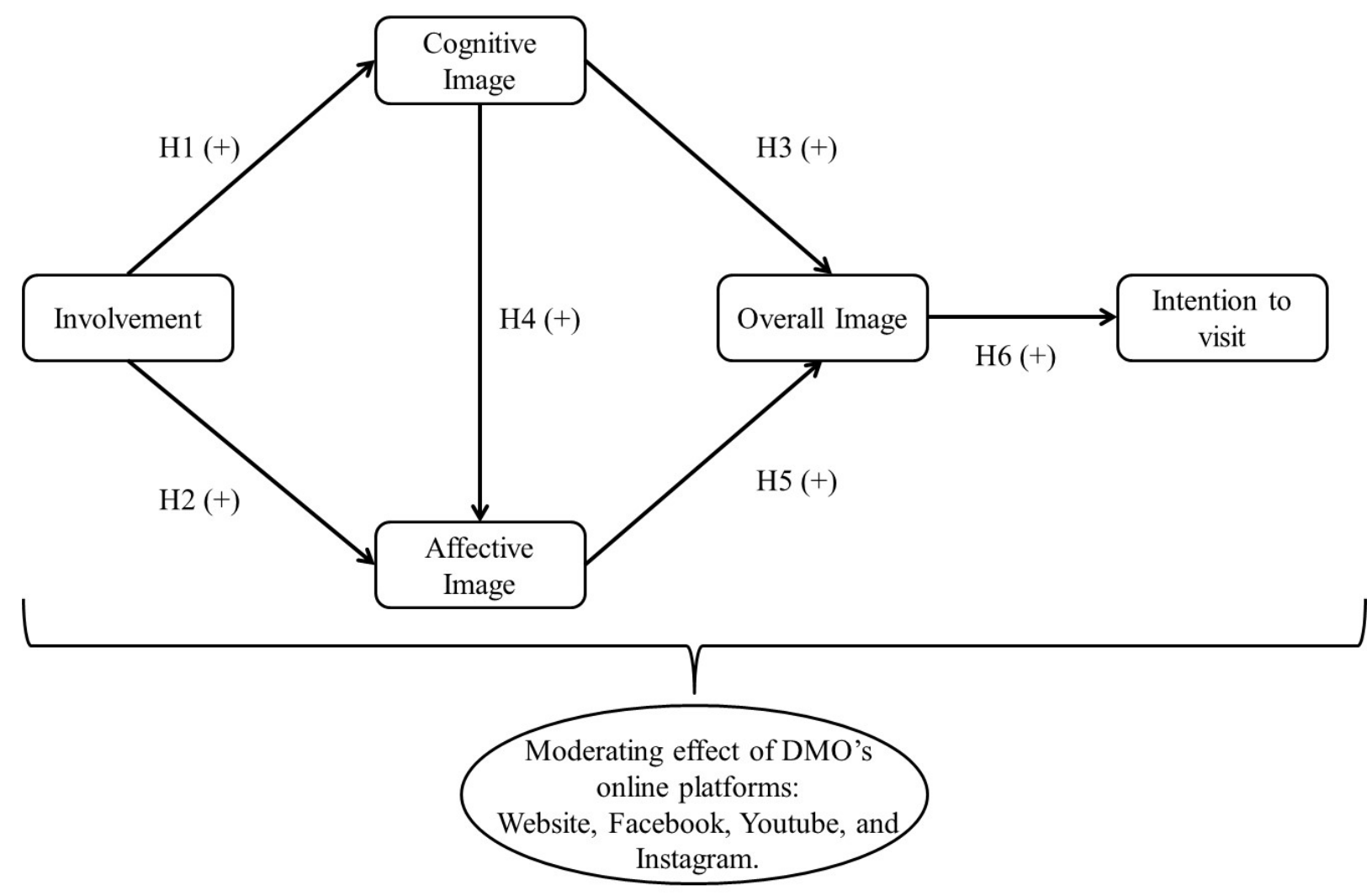

Fig. 1. Research model.

\section{Methodology}

\subsection{Procedures and sample}

Experimental design was carried out for the purposes of this study. The experiment involved presenting the available information about a tourist destination to Spanish Millennials through an official website and social media. In Spain, young people accounted for $41.2 \%$ of the total of individual travelers in 2013 and $47.9 \%$ of the people who purchased tourism products online (State Organization for Management of Tourism Innovation and Technology [Segittur], 2014).

The procedure consisted of four phases. First, we analyzed the most common platforms among DMOs and reached the conclusion of a differentiation between the official website 
and social media. Considering that the tourist DI is primarily visual (Xiong et al., 2015) and that the image in social media is primarily represented through photos and videos (Munar \& Jacobsen, 2014), three different social media platforms were selected based on different information formats and number of users: Facebook, YouTube, and Instagram. Facebook permits the creation of visible profiles with personal information, communication among users, following organizations and brands, and sharing all kinds of content (Davies, Musango, \& Brent, 2016). YouTube is the most widely used community for sharing content in video format in the world, allowing for comments and likes, among other functions (Smith, Fischer, \& Chen, 2012). Instagram was designed to share photos and short videos, allowing for comments, following other users and likes (Geurin-Eagleman \& Burch, 2016). Facebook, YouTube, and Instagram have a high penetration rate among Internet users worldwide (Global Web Index Report, 2015). Therefore, this experiment was designed with four groups of participants, with each group viewing the information about a tourist destination for a leisure travel on a different online platform (i.e., official website, Facebook, YouTube or Instagram).

Second, in order to avoid biases in the perceived image due to prior knowledge of the location, a destination was selected that was highly unknown amongst the youths. A focus group was conducted in order to make this selection. Eight university students with different characteristics (i.e., age, gender, level of studies, etc.) were invited to a meeting to discuss tourist destinations. The moderator led the debate based on the students' degree of knowledge regarding Indonesia, Austria, Norway, Turkey, and The Netherlands, which are the tourist destinations that have experienced the greatest increase in online information searches among Spanish tourists. The students were asked questions about culture, geography, economy, and politics, among other topics. Based on the students' responses, Indonesia was identified as the 
most unfamiliar destination. Four online platforms were then designed about this destination with the same stimuli (subjects, photographs, videos, etc.) adapted to the specific format characteristics for each selected platform (website, Facebook, Instagram and YouTube) (see Appendix A). The use of control stimuli for all four online platforms was intended to prevent possible differences in the perceived image among the various platforms due to differences in the messages and platforms presented (Rodríguez-Molina et al., 2015).

Third, a pilot study was conducted with 10 university students in order to improve the composition of some of the questions and determine the time allotted for the test. Participants were instructed to browse a destination online platform and answer some questions about their perceptions. After conducting the pilot study, following Jeong et al. (2012), participants were allowed to read and comprehend all the destination information they could cover in 10 minutes and minor changes were made to the wording of the survey. University students were contacted to participate in the experiment using purposive sampling. Participants had to meet 3 different criteria: (i) Frequent social media and Internet usage; (ii) Traveling abroad (outside country of origin) at least once during the last year; (iii) The destination chosen for this research should not be familiar to them. For determining the sample size, we considered the Facebook browsing experiment conducted by Kim, Kim and Wise (2014), who recommended a minimum sample size of 45 people per group. The researchers recruited 272 university students (123 male and 142 female), between the ages of 18-31. Participants were divided randomly into four sample groups, similar in size, each of which was given one experimental session.

Four, each group participated in its own browsing session at a technology laboratory. The platform was assigned at random, so that each group only viewed the information on one of 
the selected online platforms: official website, Facebook, YouTube, and Instagram. During these sessions, the participants were asked to visit the online platform and read as much travel information as they wished, and then fill out the online questionnaire. Each session consisted of five phases: (i) screening questions; (ii) questions to understand the sample tourist profile; (iii) 10-minute visit to the online platform assigned to that sample group; (iv) once the allotted time was up, the individual was redirected to the survey, to respond the questions for measuring the model's constructs; (v) sociodemographic questions. Similar to the study by Marlow and Dabbish (2014), our participants were screened to account for prior knowledge of the destination, and those candidates who already had information about said destination were excluded from the study.

The independence of the four sub-samples was verified through $\chi^{2}$ and t-student tests of the gender, age and experience variables for the survey participants, which had results with significantly different values ( $\mathrm{p}<0.001)$. The final sample consisted of 265 valid questionnaires, once the incomplete and inconsistent questionnaires were eliminated. Table 1 presents the participants’ characteristics.

\subsection{Variable measurement}

All of the variables were measured using scales adapted from previous studies. A 7-point Likert scale with 5 items was used to measure involvement (I), based on the scale developed by Rodríguez-Molina et al. (2015). To measure cognitive image (CI), a scale was adapted from Ekinci and Hosany (2006) based on 4 bipolar items (friendly/unfriendly; accessible/isolated; lively/stagnant; interesting/boring). Affective image (AI) was measured using the scale proposed by Hosany et al. (2006), also consisting of 4 bipolar items (arousing/sleepy; pleasant/unpleasant; exciting/gloomy; relaxing/distressing). In cognitive 
and affective items the positions of positive and negative pole descriptors were randomized to minimize the halo effect bias (Ekinci \& Hosany, 2006). Overall image (OI) was measured based on one question about the overall impression of Indonesia as a tourist destination, in accordance with Lin et al. (2007) and Smith et al. (2015). The intention to visit (IV) Indonesia was measured based on 5 items, 2 of which were used by Van der Veen and Song (2013) to measure the probability of the possibility of visiting the country in the next 12 months, and 3 of which were based on questions from Álvarez and Campo (2014) to measure the intention to visit the country in the future (Appendix B).

\section{Table 1}

Sample characteristics.

\begin{tabular}{lrr}
\hline Variable & Frequency & Percentage \\
\hline Gender & & \\
Male & 123 & $46.42 \%$ \\
Female & 142 & $53.58 \%$ \\
Age & & \\
$18-24$ & 237 & $89.43 \%$ \\
$25-31$ & 28 & $10.57 \%$ \\
Monthly income & & \\
No income & 42 & $15.85 \%$ \\
Under $901 €$ & 31 & $11.70 \%$ \\
901 to $1200 €$ & 36 & $13.58 \%$ \\
1201 to $1500 €$ & 45 & $16.98 \%$ \\
1501 to $1800 €$ & 31 & $11.70 \%$ \\
1801 to $2400 €$ & 35 & $13.21 \%$ \\
2401 to $3000 €$ & 21 & $7.92 \%$ \\
Over $3000 €$ & 24 & $9.06 \%$ \\
Social network profile & & \\
Yes & 265 & $100.00 \%$ \\
No & 0 & $0 \%$ \\
Time spent on social networks daily & & \\
Under 30 minutes & & \\
Up to 1 hour & 45 & $16.98 \%$ \\
Up to 2 hours & 70 & $26.42 \%$ \\
Up to 3 hours & 71 & $26.79 \%$ \\
Over 3 hours & 46 & $17.36 \%$ \\
& 33 & $12.45 \%$ \\
\hline
\end{tabular}




\section{4. $\quad$ Results}

The partial least squares (PLS) regression method was used to analyze the data in a structural equation model (SEM), as this technique is more appropriate for exploratory research and studies with small sample sizes (Fornell \& Bookstein, 1982). Moreover, PLS algorithm shows greater convergence in its simplicity, offering fewer restrictions on data normality (Chin, Marcolin, \& Newsted, 2003; Tenenhaus, Vinzi, Chatelin, \& Lauro 2005). The sample size in this study exceeds the minimum value of ten times the largest number of inner model paths directed at a particular construct in the inner model (Barclay, Higgins, \& Thompson, 1995).

SmartPLS3 software was used to analyze the data (Ringle, Wende, \& Becker, 2015). The stability of the estimates was tested via a bootstrap resampling procedure (500 resamples) (Roldán \& Sánchez-Franco, 2012). The PLS model is analyzed in two stages: First, by assessing the reliability and validity of the measurement model, and second, by assessing the structural model (Anderson \& Gerbing, 1988). Finally, a multi-group analysis to assess differences across platforms (i.e., website, Facebook, YouTube, and Instagram) was performed.

\section{1. $\quad$ Assessment of the measurement model}

In order to evaluate the measurement model, it is necessary to estimate the measurement instruments' precision in providing figures free of random errors (reliability of items and variables) and the extent to which the figures obtained with the scale reflect the true differences between the objects and the features being measured (convergent and discriminant validation). 
The individual reliability of each item is evaluated by examining the simple correlations between the indicators and their respective variables. Values over 0.7 imply that the shared variance between the construct and its indicators is greater than the error variance (Barclay et al., 1995). Table 2 shows the indicator values for the evaluation of the measurement model. The obtained results exceed the minimum recommended values in the literature.

The variable's reliability allows us to evaluate the accuracy of the items by measuring the same latent variable (internal consistency), using Cronbach’s alpha coefficient (Cronbach, 1951) and the factor's composite reliability (CR) (Nunnally \& Bernstein, 1994). The results also exceed the minimum recommended values in the literature $(0.7)$.

\section{Table 2}

Evaluation of the measurement model: composite reliability (CR), average variance extracted (AVE) and factorial loads.

\begin{tabular}{lllll}
\hline Construct & $\begin{array}{l}\text { Cronbach’s } \\
\text { alpha }\end{array}$ & CR & AVE & Factorial loads \\
& 0.814 & 0.878 & 0.643 & $0.731-0.851^{* * *}$ \\
\hline Affective Image (AI) & 0.723 & 0.827 & 0.548 & $0.767-0.811^{* * *}$ \\
Cognitive Image (CI) & 0.957 & 0.818 & $0.902-0.937^{* * *}$ \\
Involvement (Inv) & 0.994 & 1 & 1 & $1 * * *$ \\
Overall Image (OI) & 1 & 0.894 & 0.631 & $0.777-0.901^{* * *}$ \\
Intention to Visit (IV) & 0.856 & & &
\end{tabular}

Note. ${ }^{* * *} \mathrm{p}<0.001$.

The average variance extracted (AVE) is used to evaluate the convergent validity (Fornell \& Larcker, 1981). The AVE allows us to estimate the quantity variance a construct obtains from its indicators in relation to the quantity variance due to measurement error. The AVE value obtained exceeds the suggested minimum of 0.5 for all the constructs. 
Appendix C presents the means, standard deviations, skewness, and kurtosis for the research variables.

Three methods were used to evaluate the discriminant validity of PLS: (i) the examination of cross-loadings of the indicators, according to Hair, Sarstedt, Hopkins, and Kuppelwieser (2014), requires that the loadings of each indicator on its construct are higher than the crossloadings on other constructs (Table 3); (ii) the Fornell-Larcker criterion, which analyzes whether the correlations between the dimensions are lower than the square root of the AVE (Fornell \& Larcker, 1981) (Table 4); (iii) the heterotrait-monotrait (HTMT) ratio of correlations between two constructs should be below 0.9 (Henseler, Ringle, \& Sarstedt, 2015) (Table 4). All of these values were below the limit, except for one, which was slightly over the limit.

\section{Table 3}

Discriminant validity and cross loads.

\begin{tabular}{lccccc}
\hline & $\begin{array}{c}\text { Affective Image } \\
(\mathrm{AI})\end{array}$ & $\begin{array}{c}\text { Cognitive Image } \\
(\mathrm{CI})\end{array}$ & $\begin{array}{c}\text { Involvement } \\
(\text { Inv })\end{array}$ & $\begin{array}{c}\text { Overall Image } \\
(\mathrm{OI})\end{array}$ & $\begin{array}{c}\text { Intention to Visit } \\
(\mathrm{IV})\end{array}$ \\
\hline AI1 & $\mathbf{0 . 7 7 9}$ & 0.609 & 0.295 & 0.510 & 0.539 \\
AI2 & $\mathbf{0 . 8 5 1}$ & 0.596 & 0.290 & 0.465 & 0.533 \\
AI3 & $\mathbf{0 . 8 4 1}$ & 0.621 & 0.248 & 0.445 & 0.526 \\
AI4 & $\mathbf{0 . 7 3 1}$ & 0.518 & 0.291 & 0.382 & 0.365 \\
CI1 & 0.621 & $\mathbf{0 . 7 7 8}$ & 0.263 & 0.429 & 0.532 \\
CI2 & 0.485 & $\mathbf{0 . 7 6 7}$ & 0.174 & 0.350 & 0.395 \\
CI3 & 0.661 & $\mathbf{0 . 8 1 1}$ & 0.253 & 0.500 & 0.504 \\
CI4 & 0.333 & $\mathbf{0 . 7 8 5}$ & 0.198 & 0.350 & 0.276 \\
Inv1 & 0.314 & 0.257 & $\mathbf{0 . 9 0 7}$ & 0.227 & 0.130 \\
Inv2 & 0.315 & 0.238 & $\mathbf{0 . 9 1 6}$ & 0.205 & 0.119 \\
Inv3 & 0.350 & 0.287 & $\mathbf{0 . 9 3 7}$ & 0.226 & 0.104 \\
Inv4 & 0.276 & 0.305 & $\mathbf{0 . 9 0 2}$ & 0.254 & 0.156 \\
\hline
\end{tabular}




\begin{tabular}{llllll}
\hline Inv5 & 0.321 & 0.285 & $\mathbf{0 . 8 5 8}$ & 0.215 & 0.119 \\
OI & 0.565 & 0.559 & 0.249 & $\mathbf{1 . 0 0 0}$ & 0.617 \\
IV1 & 0.265 & 0.312 & -0041 & 0.331 & $\mathbf{0 . 7 7 7}$ \\
IV2 & 0.235 & 0.323 & -0.026 & 0.332 & $\mathbf{0 . 7 8 3}$ \\
IV3 & 0.625 & 0.575 & 0.194 & 0.564 & $\mathbf{0 . 8 6 4}$ \\
IV4 & 0.645 & 0.559 & 0.181 & 0.610 & $\mathbf{0 . 9 0 1}$ \\
IV5 & 0.521 & 0.504 & 0.129 & 0.520 & $\mathbf{0 . 8 1 9}$ \\
\hline
\end{tabular}

\section{Table 4}

Discriminant validity. Fornell-Larcker criterion (below the main diagonal) and HeterotraitMonotrait Ratio (HTMT) (above the main diagonal).

\begin{tabular}{llllll}
\hline Construct & AI & CI & IV & Inv & OI \\
\hline Affective Image (AI) & $\mathbf{0 . 8 0 2}$ & 0.925 & 0.683 & 0.399 & 0.624 \\
Cognitive Image (CI) & 0.734 & $\mathbf{0 . 7 4 0}$ & 0.707 & 0.363 & 0.648 \\
Intention to Visit (IV) & 0.618 & 0.594 & $\mathbf{0 . 7 9 4}$ & 0.163 & 0.639 \\
Involvement (Inv) & 0.350 & 0.304 & 0.138 & $\mathbf{0 . 9 0 4}$ & 0.257 \\
Overall Image (OI) & 0.565 & 0.559 & 0.617 & 0.249 & $\mathbf{1 . 0 0 0}$ \\
\hline
\end{tabular}

Note. Main diagonal: square root of the AVE.

\subsection{Assessment of the structural model}

A bootstrapping method (500 resamples) was used to test the significance of the path coefficients and the loadings of the full structural model (Ali, Kim, \& Ryu, 2016; Hair et al., 2014). The evaluation of the structural model meets all common requirements. First, the $R^{2}$ of each of the constructs was analyzed, which indicate the construct's quantity variance explained by the model. Falk and Miller (1992) state that the appropriate value should be greater than or equal to 0.1 . All the values in the proposed model are above the limit (AI: 
0.556; IV: 0.380; OV: 0.365) except for the cognitive image value (CI: 0.098), which is very close to the suggested lower limit.

The standardized regression path weights show the relative path weight of the factors in the endogenous variables. Chin (1998) recommends values greater than 0.3, however, values greater than 0.2 may be accepted. All the relationships in the proposed model were significant and above the recommended values, except for the relationship between involvement and affective image, which, although significant, was below the recommended value (Table 5).

\section{Table 5}

Results of hypothesis testing

\begin{tabular}{cllc}
\hline Hypothesis & Relationships & Path & Supported \\
\hline H1 & Involvement $\rightarrow$ Cognitive Image & $0.304^{* * *}$ & Yes \\
H2 & Involvement $\rightarrow$ Affective Image & $0.139^{* *}$ & Yes \\
H3 & Cognitive Image $\rightarrow$ Overall Image & $0.311^{* * *}$ & Yes \\
H4 & Cognitive Image $\rightarrow$ Affective Image & $0.691^{* * *}$ & Yes \\
H5 & Affective Image $\rightarrow$ Overall Image & $0.337^{* * *}$ & Yes \\
H6 & Overall Image $\rightarrow$ Intention to Visit & $0.617^{* * *}$ & Yes \\
\hline
\end{tabular}

Note. ${ }^{* * *} \mathrm{p}<0.001, * * \mathrm{p}<0.05$

In addition, the Stone-Geisser test or $\mathrm{Q}^{2}$ (Geisser, 1975; Stone, 1974) was estimated using the blindfolding procedure (Omission Distance $=7$ ), resulting in values greater than 0.4 , which is consistent with the literature. The larger $\mathrm{Q}^{2}$ the more relevant the predictive model.

Furthermore, the size of the effect $\left(\mathrm{f}^{2}\right)$ also verified the suitability of the proposed model. This coefficient measures whether an independent latent variable has a substantial effect on a dependent latent variable. Values of $\mathrm{f}^{2}$ from $0.02-0.15,0.15-0.35$, and 0.35 or greater indicate that an exogenous latent variable has a small, medium, and large impact, respectively 
(Chin, 1998). This model shows only a minor impact of involvement on cognitive $\left(f^{2}=0.102\right)$ and affective image $\left(\mathrm{f}^{2}=0.040\right)$.

Lastly, the value of the standardized root mean square residual (SRMR) (Henseler et al., 2015) compares the difference between the observed correlation and the predicted correlation as an adjustment measurement for the model. Values under 0.08 are considered to be acceptable; the proposed model has a value of 0.07 , and is therefore considered to have a proper fit. The results of the analysis confirm all of the proposed hypotheses since they verify their significance.

\subsection{Assessment of differences across platforms}

Once the measurement model and structural model were evaluated, the moderating effects of the DMO online platforms as information sources (official website, Facebook, YouTube and Instagram) were analyzed using a multi-group PLS analysis. In order to identify a common model for the four analyzed information sources after their evaluation, we compared pairs of regression coefficients or path weights between structural models using a modified version of Student’s t-test for independent samples (Goodman \& Blum, 1996). Chin’s (2000) recommended statistical comparison procedure was used to develop a multi-group analysis based on implementation in previous research (Lu et al., 2015). A Student's t-test was used with a parametric analysis, testing $m+n+2$ degrees of freedom. For this analysis, the official website was compared to the three social media platforms viewed by the tourists in the sample. The results of each of the four models are shown in Figure 2.

The findings show that involvement has a significant, positive effect on CI and AF in both 
Facebook and Instagram. However, the official website and YouTube did not show the same effect. In addition, the findings reveal that CI has a significant, positive effect on AI for all the platforms, and the same goes for OI except in the case of Facebook. Finally, the results indicate a significant, positive effect of OI on IV for all the platforms.

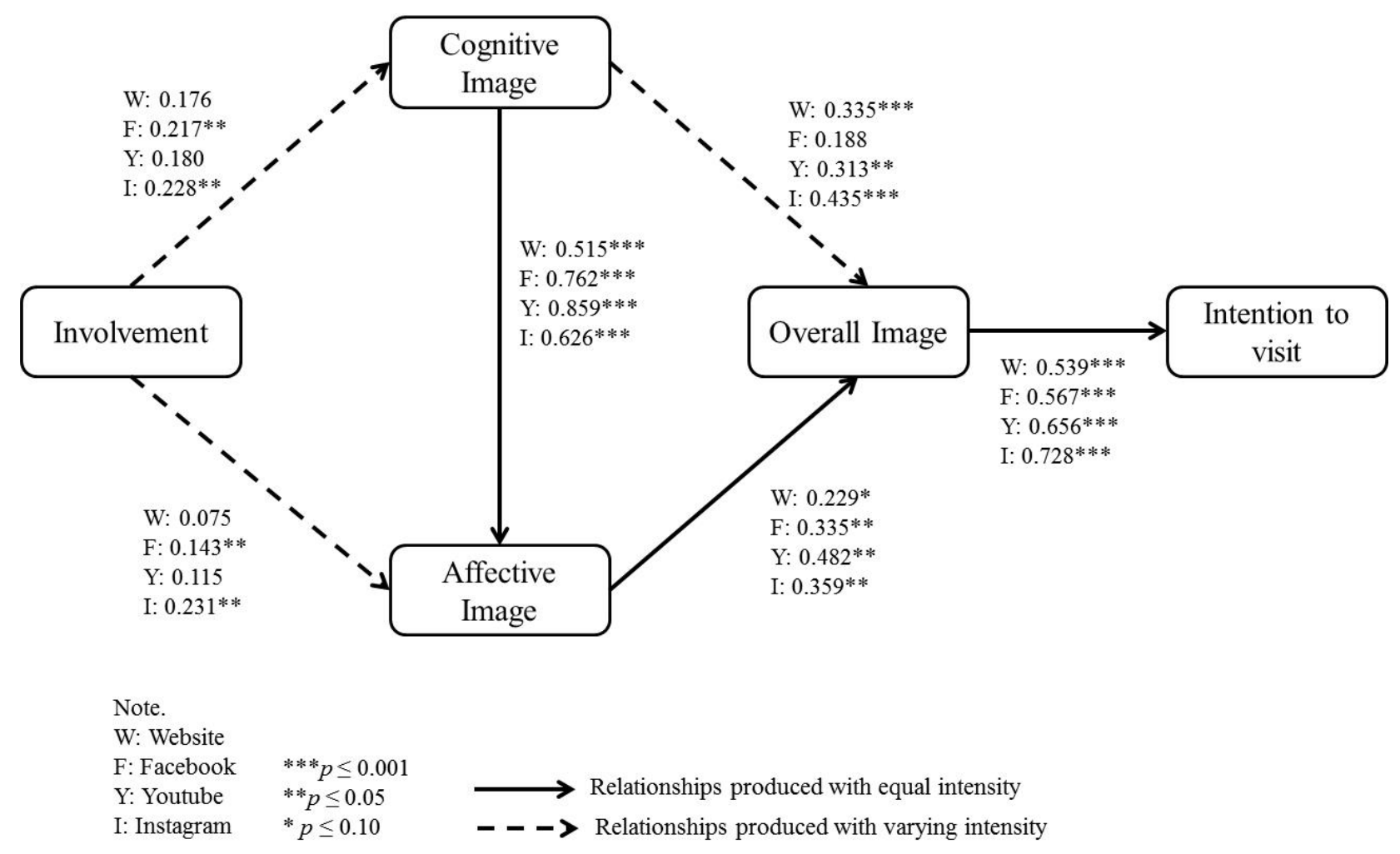

Fig. 2. Website/Facebook/YouTube/Instagram behavioral models.

The value of $\mathrm{R}^{2}$ indicates how much of the construct's variance can be explained by the model, with values around $0.19,0.33$ and 0.67 , which are considered to be weak, moderate and substantial, respectively (Chin, 1998). The comparison of the four models shows that the $\mathrm{R}^{2}$ value of the intention to visit variable is different in each model. The highest value in the model therefore stands out, with data from Instagram $\left(\mathrm{R}^{2}=0.530\right)$, followed by YouTube $\left(\mathrm{R}^{2}=0.430\right)$, Facebook $\left(\mathrm{R}^{2}=0.322\right)$ and finally the official website $\left(\mathrm{R}^{2}=0.291\right)$. 
The significant differences between the relationships in the models are shown in bold in

Table 6. The p values of the differences between path coefficients that are lower than 0.05 or higher than 0.95 indicate differences between specific path coefficients across two groups at the 5\% significance level (Sarstedt, Henseler, \& Ringle, 2011). The permutation test also returned a p value. In this case, differences were only at the 5\% significance level if the p value is smaller than 0.05 (Rasoolimanesh, Ringle, Jaafar, and Ramayah, 2017). In terms of the comparison between the Website and Facebook models, and the Website and YouTube models, significant differences were only found in the relationship between cognitive image and affective image ( $p=0.023$ and $p=0.002$, respectively). In contrast, significant differences were found in three relationships in the Website and Instagram model comparison: i) cognitive image and overall image ( $\mathrm{p}=0.050)$; ii) affective image and overall image $(\mathrm{p}=0.001)$; iii) overall image and intention to visit $(\mathrm{p}=0.000)$.

\section{Table 6}

Comparison of the Website model versus Facebook, YouTube and Instagram models.

\begin{tabular}{|c|c|c|c|c|c|c|c|c|c|c|c|c|c|c|}
\hline \multirow{2}{*}{ Relationship } & \multicolumn{2}{|c|}{ Web } & \multicolumn{2}{|c|}{ Facebook } & \multicolumn{2}{|c|}{ YouTube } & \multicolumn{4}{|c|}{ Instagram $\mathrm{W}$ vs $\mathrm{F}$} & \multicolumn{2}{|c|}{$\mathrm{W}$ vs $\mathrm{Y}$} & \multicolumn{2}{|l|}{ W vs I } \\
\hline & $\beta_{\mathrm{W}}$ & SE & $\beta_{\mathrm{F}}$ & SE & $\beta_{\mathrm{Y}}$ & SE & $\beta_{\mathrm{I}}$ & SE & $\mathrm{t}$ & $\mathrm{p}$ & $\mathrm{t}$ & $\mathrm{p}$ & $\mathrm{t}$ & $\mathrm{p}$ \\
\hline $\mathrm{Inv} \rightarrow \mathrm{CI}$ & .176 & 266 & 217 & 135 & .180 & .146 & .228 & .148 & .137 & .891 & .012 & .990 & .195 & .846 \\
\hline $\mathrm{Inv} \rightarrow \mathrm{AI}$ & .075 & .152 & .143 & .070 & -.115 & .093 & .231 & .095 & .405 & .686 & -1.063 & .289 & 1.780 & .077 \\
\hline $\mathrm{CI} \rightarrow \mathrm{OI}$ & .335 & .129 & .188 & .142 & .313 & .146 & .435 & .133 & -.770 & .443 & -.112 & .911 & 1.959 & .050 \\
\hline $\mathrm{CI} \rightarrow \mathrm{AI}$ & .515 & .096 & .762 & .048 & .859 & .046 & .626 & .073 & 2.300 & .023 & 3.233 & .002 & -.911 & .364 \\
\hline $\mathrm{AI} \rightarrow \mathrm{OI}$ & .229 & .142 & .335 & .160 & .482 & .159 & .359 & .142 & .497 & .620 & 1.188 & .237 & 3.332 & .001 \\
\hline $\mathrm{OI} \rightarrow \mathrm{IV}$ & .539 & 099 & .567 & .090 & .656 & .071 & .728 & .049 & .210 & .834 & .957 & .340 & -5.453 & .000 \\
\hline
\end{tabular}

Note. Significant differences are shown in bold. $\mathrm{W}=$ official website; $\mathrm{F}=$ Facebook; $\mathrm{Y}=$ YouTube; I=Instagram; $\mathrm{t}=\mathrm{t}-$ Student; $\mathrm{p}=\mathrm{p}$-value

The results indicate that the proposed model is not fully generalizable. The relationships between involvement and cognitive image, as well as between involvement and affective image were confirmed for the Facebook and Instagram models. The significance of the 
relationships between cognitive image and overall image was confirmed for the Website, YouTube and Instagram models. Finally, the relationships between cognitive image and affective image, affective image and overall image, as well as between overall image and intention to visit were confirmed in all the models. These results suggest that only the relationships in hypotheses 4, 5 and 6 are generalizable. The "cognitive image - affective image - overall image - intention to visit” route presents a significant validation for all the models. Consequently, the elements derived from cognitive aspects are an antecedent of the emotional aspects in the tourist DI valued by visitors prior to their intention to visit.

\section{Discussion and conclusions}

Prior research has not assessed the relationship between involvement and the cognitive and affective image dimensions on the Internet. This study contributes to closing this gap by empirically exploring the moderating effects of DMO online platforms through a research model that links tourist involvement, cognitive image, affective image, overall image, and intention to visit, in the context of Millennial leisure travelers.

The study contributes to the existing literature on DI by responding to the suggestion of Josiassen et al. (2016) to introduce moderating variables in the DI model, as well as the need to improve knowledge of the impact of DMO websites (Tigre Moura et al., 2015) and social media (Költringer \& Dickinger, 2015) on DI. Most of the previous studies on this subject have analyzed how different types of online platforms (e.g., official tourism websites, blogs, social networking sites, content communities, etc.) influence DI formation (e.g., Kladou \& Mavragani, 2015; Költringer \& Dickinger, 2015; Llodrà-Riera et al., 2015). None of these studies have explored the moderating effect of DMO's different online platforms on DI and 
the intention to visit. Failure to take into account the impact of an online information platform on DI could have serious negative consequences on the DMOs' marketing strategies for attracting tourists. This study also contributes to the existing literature by analyzing the effect of involvement on cognitive and affective image, which brings differences to light that were previously unknown.

The results show that involvement has a significant, positive effect on CI and AI for Facebook and Instagram, although this effect is not significant for the official website or YouTube. In addition, CI has a direct, positive effect on AI for all the platforms, as well as on OI except in the case of Facebook. Finally, the relationships between AI and OI, and OI and IV are significant for all the platforms. The latter two relationships were produced with equal intensity whereas the other analyzed relationships were produced with varying intensity.

The research model is parsimonious and its predictive validity is moderate, showing significant differences in how DMO online platforms affect DI and the intention to visit. The findings also have strategic implications for tourist destination managers to use social media and websites more efficiently in order to improve DI and the intention to visit.

\section{Table 7}

DMO online platforms' performance in the image formation process

DMO online platform Performance

It requires a high degree of user involvement, although its influence on the cognitive and affective image is essentially non-existent. It

Official website results in the best perception of the destination image (i.e., CI, AI, and OI) out of the four platforms considered in this study, as well as the highest intention to visit. However, the influence of the cognitive image and the overall image on the intention to visit is significantly 
less than for Instagram. It is a very interesting platform for creating the destination image, although it requires a high level of attention from users and only very moderately explains the intention to visit.

This social media site is the most differentiated from the official website in terms of the destination image construction process. It's a good platform for building and promoting the destination image without requiring a high level of involvement from users. It favors the influence of the cognitive and affective dimensions on the Instagram perception of the overall image. The perceived image has a major influence on the intention to visit. Both the perceived image and the intention to visit obtained higher values than the other two social media platforms considered in this study. The model explains over $50 \%$ of the variance of the intention to visit. It's a very interesting platform for building the destination image and attracting tourists.

Similarly to the official website, it requires a high level of user involvement, which has a positive influence on the perception of the cognitive and affective image. Nevertheless, the perceived overall

Facebook image and the intention to visit have lower values than the website and Instagram. It also explains the variance of the intention to visit less than the Instagram and YouTube models. Its contribution to attracting tourists does not appear to be very significant.

This platform requires the least amount of user involvement, although its influence on the cognitive and affective image is essentially non-existent. The perceived image (i.e., cognitive,

YouTube affective, and overall) obtained the lowest values out of the four platforms considered in this study, as well as the lowest intention to visit. This seems to be the platform that contributes the least to attracting visitors. 
Firstly, the findings show that tourist involvement in the process of obtaining and analyzing information positively affects a destination's cognitive and affective image. This result is consistent with prior studies that demonstrated the effect of involvement on the overall image construct (e.g., Lu et al., 2015; Prayag \& Ryan, 2012; Rodríguez-Molina et al., 2015) and cognitive image (Martín-Santana et al., 2017). This study therefore improves knowledge since it distinguishes between the impact on cognitive image and affective image, the first of which appears to be more significant, and we consider this to be a relevant contribution. Furthermore, through multi-group analysis, it can be observed that this relationship is only significant in the case of Facebook and Instagram. However its effect is not statistically substantiated for official website or YouTube. This may be due to different tourists' uses and perceptions of each platform. Therefore, a DMO can leverage tourist involvement in the DI formation process by providing useful, appropriate information in an attractive way, which is easy to interpret and more viable through the use of images. Involvement may also be related to trust and therefore, the DMO should facilitate tourist participation and interaction in creating content, especially on social media.

This study also confirms the positive effect of cognitive image on affective image. The results demonstrate a strong influence of cognitive image on affective image in line with the findings of recent studies (e.g., Kim \& Stepchenkova, 2015; Tan \& Wu, 2016). This finding is a novelty since it is the first time that significant differences in the relationships between cognitive and affective image have been explored by comparing the official website and Facebook models, as well as comparing the official website and YouTube models. In both cases, the influence of cognitive image on affective image is greater in social media. Social media are valued by tourists due to the wealth of information they provide (Költringer \& Dickinger, 2015) in a useful way that is easy to interpret and enjoy (Ayeh et al., 2013). 
Therefore, DMOs have to facilitate content creation for cognitive aspects of the destination, such as infrastructure, environmental practices, cleaning, safety, etc. This is especially true for social media since it has also been proven that the image communicated by tourists through their photos also implies other topics of interest that are not usually reflected in the images created by the DMO itself (Stepchenkova \& Zhan, 2013).

The findings also support the two-dimensional concept of overall image, in line with the literature (e.g., Baloglu \& McCleary, 1999; Hallmann et al., 2015; Lin et al., 2007; Smith et al., 2015), as well as the important effect of overall image on the intention to visit the destination (Tan \& Wu, 2016). These relationships, which are generally significant across all platforms, with the exception of one on Facebook, only present substantial differences when comparing the website and Instagram models. This may be due to the major differences in format, type and origin of the information users usually can view in different platforms, as previously mentioned.

Therefore, the differences observed in the multi-group analysis between platforms indicate that the proposed model is not fully generalizable, since the proposed relationships have different values. Specifically, the Instagram model stands out as having a better fit across all relationships. This may be due to the platform's specific characteristics. On the one hand, social media favor user participation and engagement, in contrast to the official website, as users find it to be a familiar, trustworthy medium. On the other hand, in contrast to YouTube and Facebook, processing the information on Instagram solely based on photographs requires a lower degree of user involvement and allows for the construction of an attractive cognitive and affective image of the destination using stimuli that are not very complex and are easy to process. The model also predicts an important component of the intention to visit a 
destination in the case of YouTube, Facebook and the official website, in this order. These results are consistent with those obtained in previous studies (e.g., Jeong et al., 2012; Tan \& Wu, 2016; Tigre Moura et al., 2015), and offer a new comparison of the performance of each of the four types of platforms that are regularly used by DMOs. 


\section{Appendix A}

Stimuli.

\section{Facebook}

Gesr up, paddle and get set to ride the rolling waves of G-and at Banyuwangi. PNeve the bustling world behind and experience exciting new thrils in the most beoutiful natural surroundings

"Wondertullindonesia

Video Kylor Melton 8 Mikai Kan

Music James Everingham

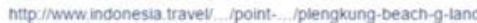

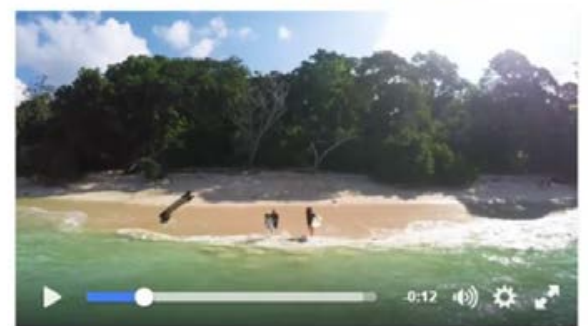

Come taste the delicious beef Rendang, dubbed by CNN Go as the Worla: Most Favonte Dish West Sumatera offers many traditional culsine rich in inondertulindonesia

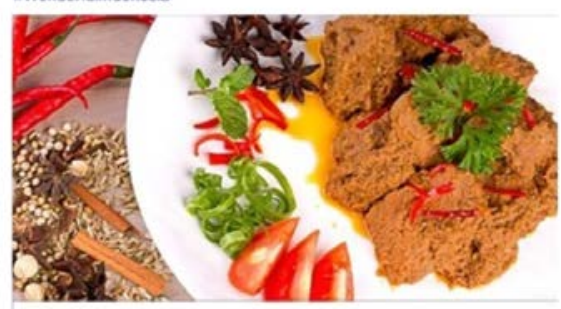

Rendang

Rendang was chosen by CNW Go as wordiss tavorite tood Eiploce our websine of

Come witness real-ife dragons in their own habieat at the Komodo National Park The Komodo Dragon cant breathe free, but they can move super fast and are Just as dangerous as real dragons when they feel threasened.

awondertulindonesia

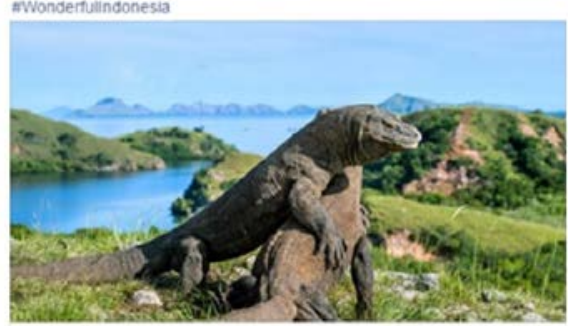

Komodo National Park

Getreal dose to the wonds largestizards on Komodo istand. Dive into the

wis Discever mote on indonesia travel

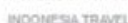
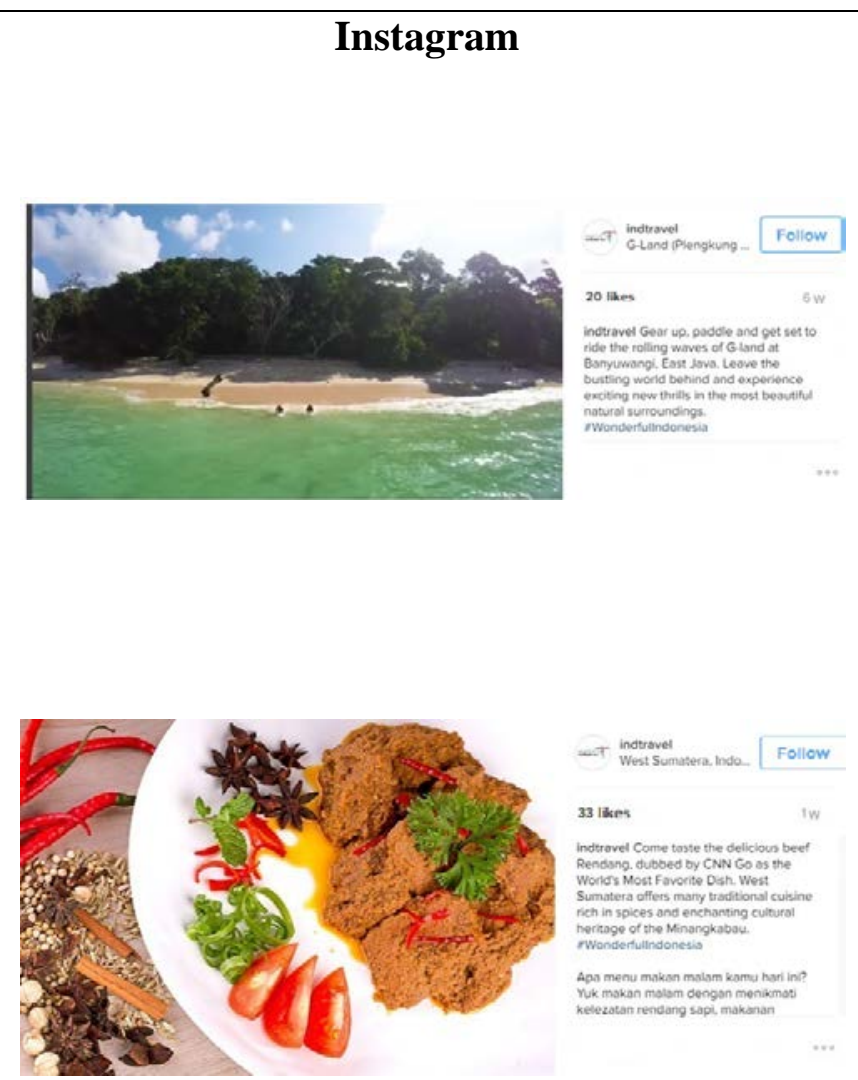

33 likes

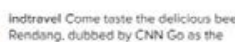

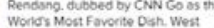

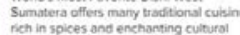

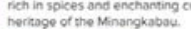

Aps menu makas molsm kamu har ins?

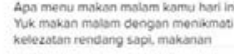
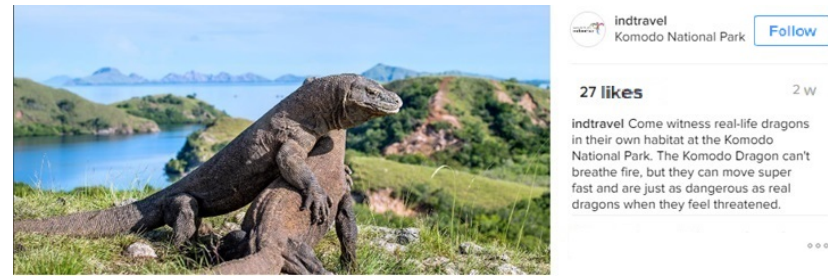

27 likes

intravel Come witness real-ifie dragols

In their own habitat at the Komodo breathe fire, but they can move super
fast and are just as dangerous as real 




Wonderful Indonesia: A Visual Journey through Banyuwangi

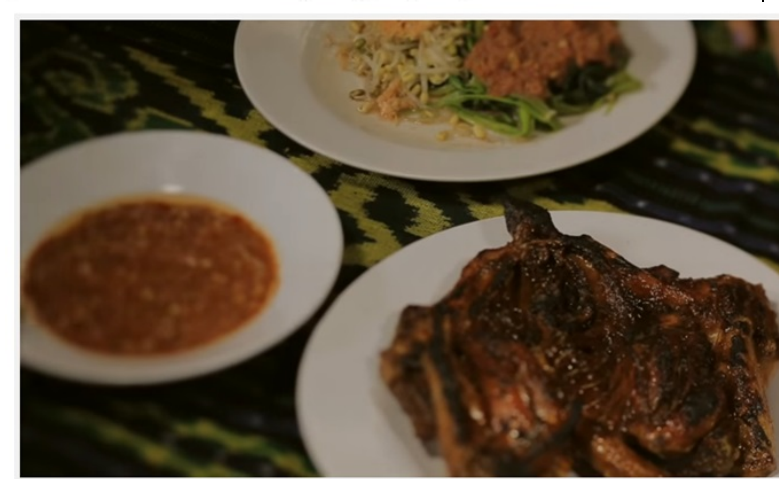

Wonderful Indonesia : Culinary

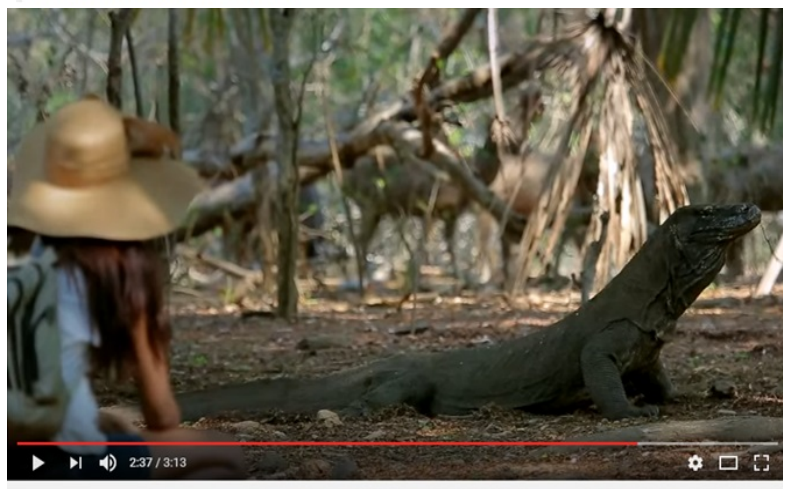

Wonderful Indonesia | Komodo Labuan Bajo

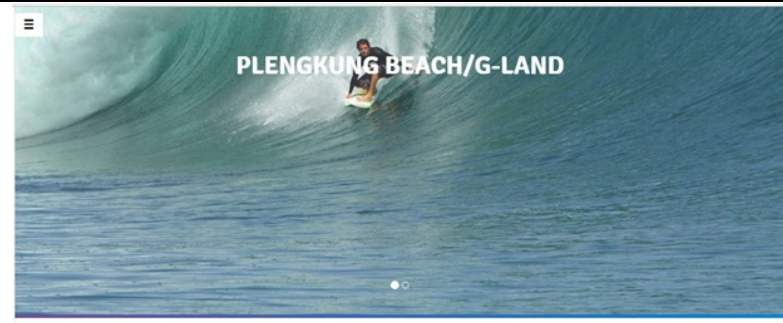

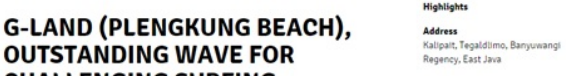

CHALLENGING SURFING

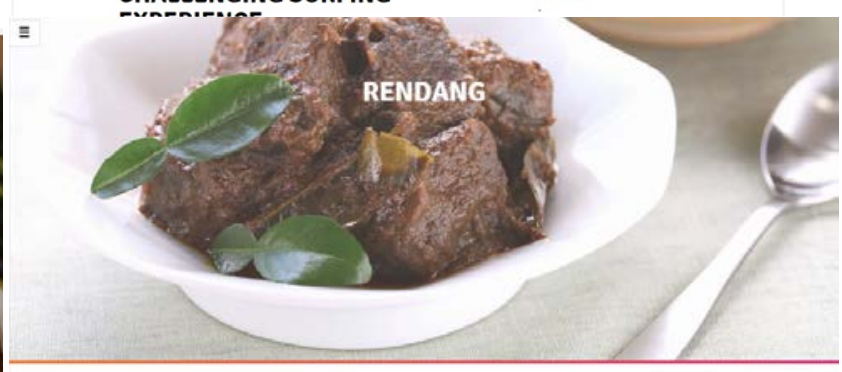

ENJOY THE FAMOUS RENDANG RECIPE IN PASAR ATAS

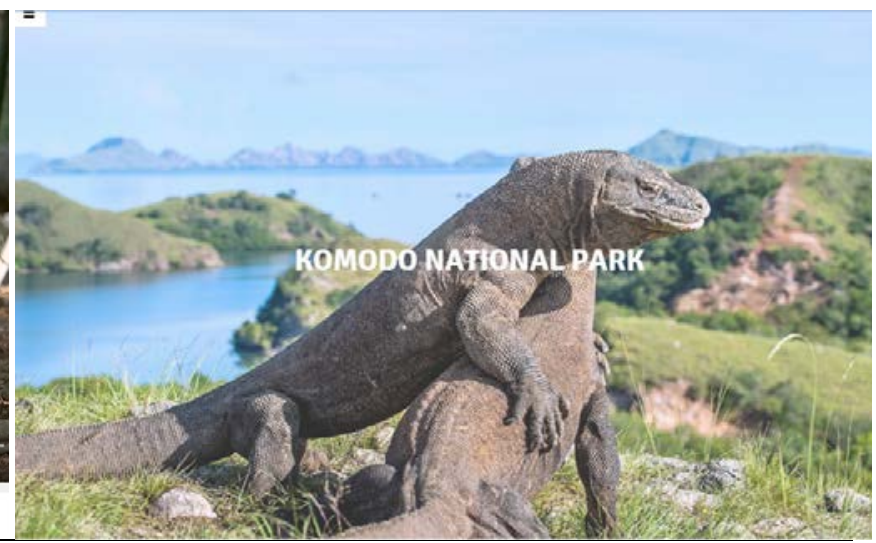




\section{Appendix B}

Measurement scales.

Construct, code and items

Involvement

I1. How much attention did you pay to

the website information?

I2. How much did you notice the

website information?

I3. How much did you concentrate on the website information?

I4. How involved were you with the website information?

I5. How much thought did you put into evaluating the website information?

Cognitive image

CI1. From extremely friendly to extremely unfriendly

CI2. From extremely accessible to extremely isolated

CI3. From extremely lively to extremely stagnant

CI4. From extremely interesting to extremely boring

Affective image

AI1. Arousing /sleepy

AI2. Pleasant /unpleasant

AI3. Exciting /gloomy

AI4. Relaxing /distressing

Overall image

OI. How would you rate your overall

feeling toward Indonesia as a tourism destination?

Type of scale Source

7-point scale from low

Rodríguez-Molina et al., to high 2015.

7-point semantic

differential scales
Ekinci and Hosany, 2006; Smith et al., 2015. 7-point semantic

differential scales

7- point scale from

worst to best
Hosany et al., 2006; Lin et al., 2007; Smith et al., 2015.

Lin et al., 2007; Smith et al., 2015. 
Intention to visit

How likely is it that you will visit

7- point semantic

Van der Veen and Song,

Indonesia in the next 12

differential scales

2013.

months?

IV1. Probable-improbable

IV2. Likely-unlikely

IV3. I intend to visit Indonesia in the near future

7- point scale from

Álvarez and Campo,

IV 4. I would choose Indonesia as the

highest disagreement 2014.

destination form my next holidays

level to highest

IV5. I would prefer to visit Indonesia

agreement

as opposed to other similar destinations 


\section{Appendix C}

Variable descriptive statistics.

\begin{tabular}{|c|c|c|c|c|c|c|c|c|}
\hline & M & SD & Skewness & Kurtosis & $\begin{array}{c}\text { M } \\
\text { Facebook }\end{array}$ & $\begin{array}{c}\text { M } \\
\text { Youtube }\end{array}$ & $\begin{array}{c}\text { M } \\
\text { Instagram }\end{array}$ & $\begin{array}{c}\text { M } \\
\text { Web }\end{array}$ \\
\hline AI1 & 5.34 & 1.433 & $\begin{array}{l}-0.823 \\
\end{array}$ & 0.345 & 5.36 & 4.71 & 5.29 & 5.81 \\
\hline AI2 & 5.35 & 1.395 & -0.858 & 0.680 & 5.63 & 4.49 & 5.23 & 5.74 \\
\hline AI3 & 5.56 & 1.405 & -1.045 & 0.952 & 5.71 & 4.78 & 5.56 & 5.95 \\
\hline AI4 & 5.24 & 1.518 & -0.683 & -0.202 & 5.45 & 3.85 & 5.21 & 6.03 \\
\hline CI1 & 4.86 & 1.363 & -0.362 & -0.371 & 5.11 & 4.02 & 4.71 & 5.28 \\
\hline CI2 & 4.15 & 1.313 & -0.092 & -0.311 & 4.16 & 3.80 & 3.65 & 4.71 \\
\hline CI3 & 5.20 & 1.338 & -0.352 & -0.515 & 5.53 & 4.71 & 4.98 & 5.36 \\
\hline CI4 & 5.66 & 1.291 & -0.883 & 0.470 & 5.95 & 4.85 & 5.52 & 6.01 \\
\hline Inv1 & 4.42 & 1.558 & -0.575 & -0.381 & 4.98 & 3.27 & 4.19 & 4.81 \\
\hline Inv2 & 4.42 & 1.620 & -0.592 & -0.533 & 5.00 & 3.44 & 4.19 & 4.67 \\
\hline Inv3 & 4.02 & 1.530 & -0.147 & -0.731 & 4.50 & 2.98 & 3.69 & 4.49 \\
\hline Inv4 & 3.99 & 1.548 & -0.265 & -0.739 & 4.45 & 3.09 & 3.73 & 4.32 \\
\hline Inv5 & 3.97 & 1.558 & -0.313 & -0.655 & 4.56 & 3.05 & 3.56 & 4.29 \\
\hline $\mathrm{OI}$ & 5.30 & 1.549 & -0.841 & 0.146 & 5.24 & 4.65 & 5.38 & 5.76 \\
\hline IV1 & 3.12 & 2.192 & 0.530 & -1.243 & 2.63 & 3.07 & 3.81 & 3.21 \\
\hline IV2 & 3.21 & 2.107 & 0.557 & -1.110 & 2.89 & 3.13 & 3.63 & 3.31 \\
\hline IV3 & 5.22 & 1.691 & -0.702 & -0.405 & 5.16 & 4.58 & 5.31 & 5.65 \\
\hline IV4 & 4.96 & 1.773 & -0.551 & -0.716 & 4.94 & 4.22 & 5.04 & 5.46 \\
\hline IV5 & 4.26 & 1.590 & -0.247 & -0.426 & 4.10 & 3.96 & 4.23 & 4.67 \\
\hline
\end{tabular}

Note. $\mathrm{M}=$ Mean; SD = Standard Deviation. 


\section{References}

Ali, F., Kim, W. G., \& Ryu, K. (2016). The effect of physical environment on passenger delight and satisfaction: Moderating effect of national identity. Tourism Management, 57, 213-224.

Álvarez, M. D, \& Campo, S. (2014). The influence of political conflicts on country image and intention to visit: A study of Israel's image. Tourism Management, 40, 70-78.

Anderson, J. C., \& Gerbing, D. W. (1988). Structural equation modeling in practice: A review and recommended two-step approach. Psychological Bulletin, 103(3), 411423.

Avraham, E. (2015). Destination image repair during crisis: Attracting tourism during the Arab Spring uprisings. Tourism Management, 47, 224-232.

Ayeh, J. K., Au, N., \& Law, R. (2013). Predicting the intention to use consumer-generated media for travel planning. Tourism Management, 35, 132-143.

Baloglu, S., \& McCleary, K. W. (1999). A model of destination image formation. Annals of Tourism Research, 26(4), 868-897.

Barclay, D., Higgins, C., \& Thompson. R. (1995). The Partial Least Squares (PLS) Approach to Causal Modeling: Personal Computer Adoption and Use an Illustration. Technology Studies, 2(2), 285-309.

Bastida, U., \& Huan, T. C. (2014). Performance evaluation of tourism websites' information quality of four global destination brands: Beijing, Hong Kong, Shanghai, and Taipei. Journal of Business Research, 67(2), 167-170.

Beerli, A., \& Martín, J. D. (2004). Tourists’ Characteristics and the Perceived Image of Tourist Destinations: A Quantitative Analysis-A Case Study of Lanzarote, Spain. Tourism Management, 25(5), 623-636.

Benckendorff, P., Moscardo, G., \& Pendergast, D. (Eds.). (2010). Tourism and Generation Y. Cambridge MA: CAB International.

Bigné, J. E., Sánchez, M. I., \& Sánchez, J. (2001). Tourism image, evaluation variables and after purchase behaviour: inter-relationship. Tourism management, 22(6), 607-616.

Bolton, R. N., Parasuraman, A., Hoefnagels, A., Migchels, N., Kabadayi, S., Gruber, T., Loureiro, Y. K., \& Solnet, D. (2013). Understanding Generation Y and their use of social media: a review and research agenda. Journal of Service Management, 24(3), 245-267.

Buhalis, D. (1993). RICIRMS as a strategic tool for small and medium tourism enterprises. Tourism Management, 14(5), 366-378.

Buhalis, D. (1998). Strategic use of information technologies in the tourism industry. Tourism Management, 19(5), 409-421.

Buhalis, D. (2000). Marketing the competitive destination of the future. Tourism Management, 21(1), 97-116.

Buhalis, D., \& Law, R. (2008). Progress in information technology and tourism management: 20 years on and 10 years after the Internet - The state of eTourism research. Tourism Management, 29(4), 609-623.

Chen, C. F., \& Tsai, D. C. (2007). How destination image and evaluative factors affect behavioral intentions? Tourism Management, 28(4), 1115-1122.

Chin, W. W. (1998). The partial least squares approach for structural equation modeling. In G. A. Marcoulides, Modern Methods for Business Research (pp. 295-236). London: Lawrence Erlbaum Associates.

Chin, W. W. (2000). Frequently Asked Questions - Partial Least Squares and PLS-Graph. http://disc-nt.cba.uh.edu/chin/plsfaq.htm (accessed April 5, 2016). 
Chin, W. W., Marcolin, B. L., \& Newsted, P. R. (2003). A partial least squares latent variable modeling approach for measuring interaction effects: Results from a Monte Carlo simulation study and an electronic-mail emotion/adoption study. Information Systems Research, 14(2), 189-217.

Cho, M.-H., \& Sung, H. H. (2012). Travel destination websites: cross-cultural effects on perceived information value and performance evaluation. Journal of Travel \& Tourism Marketing, 29(3), 221-241.

Cho, Y., Wang, Y., \& Fesenmaier, D. R. (2002). Searching for experiences: The web-based virtual tour in tourism marketing. Journal of Travel \& Tourism Marketing, 12(4), 117.

Choi, J. G., Tkachenko, T. \& Sil, S. (2011). On the destination image of Korea by Russian tourists. Tourism Management, 32(1), 193-194.

Choi, S., Lehto, X. Y., \& Morrison, A. M. (2007). Destination image representation on the web: Content analysis of Macau travel related websites. Tourism Management, 28(1), 118-129.

Chon K. S. (1991). Tourism destination image modification process: marketing implications. Tourism Management, 12(1), 68-72.

Chung, N., Lee, H., Lee, S. J., \& Koo, C. (2015). The influence of tourism website on tourists' behavior to determine destination selection: A case study of creative economy in Korea. Technological Forecasting \& Social Change, 96, 130-143.

Crompton, J. L. (1979). An assessment of the image of Mexico as a vacation destination and the influence of geographical location upon that image. Journal of Travel Research, 17(4), 18-23.

Cronbach, L. J. (1951). Coefficient alpha and the internal structure of tests. Psychometrika, 22(3), 297-334.

Davidson, R., \& Keup, M (2014). The Use of Web 2.0 as a Marketing Tool by European Convention Bureaux. Scandinavian Journal of Hospitality and Tourism, 14(3), 234254.

Davies, M., Musango, J. K., \& Brent, A. C. (2016). A systems approach to understanding the effect of Facebook use on the quality of interpersonal communication. Technology in Society, 44, 55-65.

Dichter, E. (1985). What is in an Image? Journal of Consumer Marketing, 2, 39-52.

Dion, C. P., \& Woodside, A. G. (2010). Usefulness of government and private destination websites. In A. G. Woodside (Ed.), Tourism-marketing performance metrics and usefulness auditing of destination websites, Advances in Culture, Tourism and Hospitality Research, Vol. 4. (pp. 69-137). Bingley, UK: Emerald, Advances in Culture, Tourism and Hospitality Research.

Echtner, C. M., \& Ritchie, J. R. B. (1991). The Meaning and Measurement of Destination Image. Journal of Tourism Studies, 2(2), 2-12.

Ekinci, Y., \& Hosany, S. (2006). Destination personality: An application of brand personality to tourism destinations. Journal of Travel Research, 45(2), 127-139.

Escobar-Rodríguez, T., Grávalos-Gastaminza, M. A., \& Pérez-Calañas, C. (2016). Facebook and the intention of purchasing tourism products: moderating effects of gender, age and marital status. Scandinavian Journal of Hospitality and Tourism, 17(2), 129-144.

Fakeye, P. C., \& Crompton, J. L. (1991). Image differences between prospective, first-time, and repeat visitors to the Lower Rio Grande Valley. Journal of Travel Research, 30(2), 10-16.

Falk, R. F., \& Miller, N. B. (1992). A Primer for Soft Modeling. Akron: University of Akron Press. 
Fesenmaier, D., Gretzel, U., Hwang, Y. H., \& Wang, Y. (2003). The future of destination marketing: e-Commerce in travel and tourism. International Journal of Tourism Science, 3(2), 191-200.

Fishbein, M., \& Ajzen, I. (1975). Belief, Attitude, Intention, and Behavior: An Introduction to Theory and Research. Reading, MA: Addison-Wesley Publishing Company.

Fornell, C., \& Bookstein, F. L. (1982). Two structural equation models: LISREL and PLS applied to consumer exit-voice theory. Journal of Marketing Research, 19(4), 440452.

Fornell, C., \& Larcker, D. F. (1981). Evaluating structural equation models with unobservable variables and measurement error. Journal of Marketing Research, 18(1), 39-50.

Fotis, J., Buhalis, D., \& Rossides, N. (2012). Social media use and impact during the holiday travel planning process. In M. Fuchs, F. Ricci, and L. Cantoni (Eds.), Information and Communication Technologies in Tourism (pp. 13-24). Vienna, Austria: SpringerVerlag.

Frías, D. M., Rodríguez, M. A., \& Castañeda, J. A. (2008). Internet vs. travel agencies on pre-visit destination image formation: An information processing view. Tourism Management, 29(1), 163-179.

Gallarza, M. G., Saura, I. G., \& García, H. C. (2002). Destination image: Towards a conceptual framework. Annals of Tourism Research, 29(1), 56-78.

Garay Tamajón, L., \& Cànoves-Valiente, G. (2017). Barcelona seen through the eyes of TripAdvisor: Actors, typologies and components of destination image in social media platforms. Current Issues in Tourism, 20(1), 33-37.

Gartner, W. C. (1994). Image Formation Process. Journal of Travel and Tourism Marketing, 2(2-3), 191-216.

Geisser, S. (1975). The predictive sample reuse method with applications. Journal of the American Statistical Association, 70(350), 320-328.

Geurin-Eagleman, A. N., \& Burch, L. M. (2016). Communicating via photographs: A gendered analysis of Olympic athletes' visual self-presentation on Instagram. Sport Management Review, 19(2), 133-145.

Global Web Index (2015). Global Web Index Social Q1 2015, http://insight.globalwebindex.net/social (accessed 20/9/15)

González-Rodríguez, M. R., Martínez-Torres, R., \& Toral, S. (2016). Post-visit and pre-visit tourist destination image through eWOM sentiment analysis and perceived helpfulness. International Journal of Contemporary Hospitality Management, 28(11), 2609-2627.

Goodall, B. (1991). Understanding holiday choice. In C. Cooper, Progress In Tourism, Recreation And Hospitality Management (pp. 103-133). London: Belhaven.

Goodman, J. S., \& Blum, T. C. (1996). Assessing the nonrandom sampling effects of subject attrition in longitudinal research. Journal of Management, 22, 627-652.

Govers, R., \& Go, F. (2003). Deconstructing destination image in the information age. Information Technology and Tourism, 6(1), 13-29.

Gretzel, U., Fesenmaier, D. R., Formica, S., \& O’Leary, J. T. (2006). Searching for the future: Challenges faced by destination marketing organizations. Journal of Travel Research, 45(2), 116-126.

Gretzel, U., Yuan, Y. L., \& Fesenmaier, D. R. (2000). Preparing for the new economy: Advertising strategies and changes in destination marketing organizations. Journal of Travel Research, 39(2), 146-156. 
Hair, J. F., Sarstedt, M., Hopkins, L., \& Kuppelwieser, V. G. (2014). Partial least squares structural equation modeling (PLS-SEM): An emerging tool in business research. European Business Review, 26(2), 106-121.

Hallmann, K., Zehrer, A., \& Müller, S. (2015). Perceived destination image: An image model for a winter sports destination and its effect on intention to revisit. Journal of Travel Research, 54(1), 94-106.

Havitz, M. E., \& Dimanche, F. (1990). Propositions for testing the involvement construct in recreational and tourism contexts. Leisure Sciences, 12(2), 179-195

Hays, S., Page, S. J., \& Buhalis, D. (2013). Social media as a destination marketing tool: its use by national tourism organisations. Current issues in Tourism, 16(3), 211-239.

Henseler, J., Ringle, C. M., \& Sarstedt, M. (2015). A New Criterion for Assessing Discriminant Validity in Variance-based Structural Equation Modeling. Journal of the Academy of Marketing Science, 43(1), 115-135.

Hosany, S., Ekinci, Y., \& Uysal, M. (2006). Destination image and destination personality: An application of branding theories to tourism places. Journal of Business Research, 59(5), 638-642.

Huang, Y. C., \& Petrick, J. F. (2010). Generation Y's travel behaviours: a comparison with baby boomers and generation X. In P. Benckendorff, G. Moscardo, and D. Pendergast (Eds.), Tourism and Generation Y (pp. 27-37). Cambridge MA: CAB International.

Hunt, J. D. (1975). Image as a factor in tourism development. Journal of Travel Research, 13(3), 1-7.

Hunter, W. C. (2016). The social construction of tourism online destination image: A comparative semiotic analysis of the visual representation of Seoul. Tourism Management, 54, 221-229.

Immordino-Yang, M. H., Christodoulou, J. A., \& Singh, V. (2012). Rest is not idleness: implications of the brain's default mode for human development and education. Perspectives on Psychological Science, 7(4), 352-364.

Inversini, A. Cantoni, L., \& De Pietro, M. (2014). Destination online communication: Why less is sometimes more. A study of online communications of English destinations. Journal of Travel \& Tourism Marketing, 31(5), 563-575.

Jeong, C., Holland, S., Jun, S. H., \& Gibson, H. (2012). Enhancing destination image through travel website information. International Journal of Tourism Research, 14(1), 16-27.

Josiam, B. M., Smeaton, G., \& Clements, C. J. (1999). Involvement: travel motivation and destination selection. Journal of Vacation Marketing, 5(2), 167-175.

Josiassen, A., Assaf, A. G., Woo, L., \& Kock, F. (2016). The Imagery-Image Duality Model An Integrative Review and Advocating for Improved Delimitation of Concepts. Journal of Travel Research, 55(6), 789-803.

Kim, H., \& Fesenmaier, D. (2008). Persuasive Design of Destination Web Sites: An Analysis of First Impression. Journal of Travel Research, 47(3), 3-13.

Kim, H., \& S. L. Richardson (2003). Motion Picture Impacts on Destination Images. Annals of Tourism Research, 30(1), 216-37.

Kim, H., \& Stepchenkova, S. (2015). Effect of tourist photographs on attitudes towards destination: Manifest and Latent content. Tourism Management, 49, 29-41.

Kim, S. B., Kim, D. Y., \& Wise. K. (2014). The effect of searching and surfing on recognition of destination images on Facebook pages. Computers in Human Behavior, 30, 813-823.

Kladou, S., \& Mavragani, E. (2015). Assessing destination image: An online marketing approach and the case of TripAdvisor. Journal of Destination Marketing and Management, 4(3), 187-193. 
Kock, F, Josiassen, A., \& Assaf, A. G. (2016). Advancing destination image: The destination content model. Annals of Tourism Research, 61, 28-44.

Költringer, C., \& Dickinger, A. (2015). Analyzing destination branding and image from online sources: A web content mining approach. Journal of Business Research, 68(9), 1836-1843.

Konecnik, M., \& Gartner, W. C. (2007). Customer-based brand equity for a destination. Annals of Tourism Research, 34(2), 400-421.

Lai, K., \& Li, X. R. (2016). Tourism Destination Image Conceptual Problems and Definitional Solutions. Journal of Travel Research, 55(8), 1065-1080.

Law, R., Buhalis, D., \& Cobanoglu, C. (2014). Progress on information and communication technologies in hospitality and tourism. International Journal of Contemporary Hospitality Management, 26(5), 727-750.

Law, R., Qi, S., \& Buhalis, D. (2010). Progress in Tourism Management: A Review of Website Evaluation in Tourism Research. Tourism Management, 31, 297-313.

Li, X. R., Cheng, C. K., Kim, H., \& Petrick, J. F. (2008). A systematic comparison of firsttime and repeat visitors via a two-phase online survey. Tourism Management, 29(2), 278-293.

Li, X., Li, X. R., \& Hudson, S. (2013). The application of generational theory to tourism consumer behavior: An American perspective. Tourism Management, 37, 147-164.

Lim, Y., Chung, Y., \& Weaver, P. A. (2012). The impact of social media on destination branding: consumer-generated videos versus destination marketer-generated videos. Journal of Vacation Marketing, 18(3), 197-206.

Lin, C. H., Morais, D. B., Kerstetter, D. L., \& Hou, J. S. (2007). Examining the role of cognitive and affective image in predicting choice across natural, developed, and theme-park destinations. Journal of Travel Research, 46(2), 183-194.

Llodrà-Riera, I., Martínez-Ruiz, M. P., Jiménez-Zarco, A. I., \& Izquierdo-Yusta, A. (2015). A multidimensional analysis of the information sources construct and its relevance for destination image formation. Tourism Management, 48, 319-328.

Lu, L., Chi, C. G., \& Liu, Y. (2015). Authenticity, involvement, and image: Evaluating tourist experiences at historic districts. Tourism Management, 50, 85-96.

Luna-Nevarez, C., \& Hyman, M. R. (2012). Common practices in destination website design. Journal of Destination Marketing and Management, 1(1), 94-106.

MacKay, K. J., \& Fesenmaier, D. R. (1997). Pictorial Element of Destination in Image Formation. Annals of Tourism Research, 24(3), 537-565.

MacKay, K. J., \& Fesenmaier, D. R. (2000). An Exploration of Cross-Cultural Destination Image Assessment. Journal of Travel Research, 38(4), 417-423.

MacKay, K., \& Vogt, C. (2012). Information technology in everyday and vacation contexts. Annals of Tourism Research, 39(3), 1380-1401.

Mak, A. H. (2017). Online destination image: Comparing national tourism organisation's and tourists' perspectives. Tourism Management, 60, 280-297.

Mannheim, K. (1952). The problem of generations. In P. Kecskemetim (Ed.), Essays on the Sociology of Knowledge (pp. 276-322). London, UK: Routledge \& Kegan Paul.

Mano, A., \& da Costa, R. A. (2015). A conceptual model of the antecedents and consequences of tourist destination image. Procedia Economics and Finance, 23, 1522.

Mariani, M. M., Di Felice, M., \& Mura, M. (2016). Facebook as a destination marketing tool: Evidence from Italian regional Destination Management Organizations. Tourism Management, 54, 321-343. 
Marlow, J., \& Dabbish, L. (2014). When is a picture not worth a thousand words? The psychological effects of mediated exposure to a remote location. Computers in Human Behavior, 30, 824-831.

Martín-Santana, J. D., Beerli-Palacio, A., \& Nazzareno, P. A. (2017). Antecedents and consequences of destination image gap. Annals of Tourism Research, 62, 13-25.

McGehee, N. G., Yoon, Y., \& Cárdenas, D. (2003). Involvement and Travel for Recreational Runners in North Carolina. Journal of Sport Management, 17(3), 305-324.

Michaelidou, N., Siamagka, N. T., Moraes, C., \& Micevski, M. (2013). Do marketers use visual representations of destinations that tourists value? Comparing visitors' image of a destination with marketer-controlled images online. Journal of Travel Research, 52(6), 789-804.

Munar, A. M. (2012). Social media strategies and destination management. Scandinavian Journal of Hospitality and Tourism, 12(2), 101-120.

Munar, A. M., \& Jacobsen, J. K. S. (2014). Motivations for sharing tourism experiences through social media. Tourism Management, 43, 46-54.

Nadeem, W., Andreini, D., Salo, J., \& Laukkanen, T. (2015). Engaging consumers online through websites and social media:A gender study of Italian Generation Y clothing consumers. International Journal of Information Management, 35, 432-442.

Noh, J. H. (2007). Factors influencing American's intentions to vacation in South Korea. Korean Journal of Tourism Research, 22(3), 163-182.

Nunnally, J. C., \& Bernstein, I. H. (1994). Psychometric Theory. 3rd ed. New York: McGraw-Hill.

Nusair, K., Bilgihan, A., Okumus, F., \& Cobanoglu, C. (2013). Generation Y travelers’ commitment to online social network websites. Tourism Management, 35, 13-22.

Pan, B., \& Fesenmaier, D. R. (2006). Online information search: Vacation planning process. Annals of Tourism Research, 33(3), 809-32.

Pan, B., \& Li, X. R. (2011). The long tail of destination image and online marketing. Annals of Tourism Research, 38(1), 132-152.

Pendergast, D. (2010). Getting to Know the Y Generation. In P. Benckendorff, G. Moscardo, and D. Pendergast (Eds.), Tourism and Generation Y (pp. 1-15). Cambridge MA:

CAB International.

Pew Research Center (2015). Social Media Usage: 2005-2015. http://www.pewinternet.org/files/2015/10/PI_2015-10-08_Social-Networking-Usage2005-2015_FINAL.pdf. (accessed 8/7/16)

Pike, S., \& Page, S. (2014). Destination marketing organizations and destination marketing: a narrative analysis of the literature. Tourism Management, 41, 202-227.

Poon, A. (1993). Tourism, technology and competitive strategies. Oxford: CAB International.

Prayag, G., \& Ryan, C. (2012). Antecedents of tourists' loyalty to Mauritius: the role and influence of destination image, place attachment, personal involvement, and satisfaction. Journal of Travel Research, 51(3), 342-356.

Punj, G., \& Moore, R. (2009). Information search and consideration set formation in a webbased store environment. Journal of Business Research, 62(6), 644-650.

Rasoolimanesh, S. M., Ringle, C. M., Jaafar, M., \& Ramayah, T. (2017). Urban vs. rural destinations: Residents' perceptions, community participation and support for tourism development. Tourism Management, 60, 147-158.

Richards, G. (2016). The Economic Impact of Youth Travel. In World Tourism Organization, Global Report on The Power of Youth Travel (pp. 10-13). Retrieved from:

file://J:/Publicaciones/2016\%20Destination\%20image/Bibliografia/UNWTO\%20201 6\%20Global\%20report.pdf (accessed 26/12/2016)

Ringle, C. M., Wende, S., \& Becker, J.-M. (2015). SmartPLS 3. Bönningstedt: SmartPLS. 
Rodríguez-Molina, M. A., Frías-Jamilena, D. M., \& Castañeda-García, J. A. (2015). The contribution of website design to the generation of tourist destination image: The moderating effect of involvement. Tourism Management, 47, 303-317.

Roldán, J. L., \& Sánchez-Franco, M. J. (2012). Variance-based structural equation modeling: guidelines for using partial least squares in Information Systems Research. In M. Mora, O. Gelman, A. Steenkamp, and M. S. Raisinghani (Eds.) Research Methodologies, Innovations and Philosophies in Software Systems Engineering and Information Systems (pp.193-221). Hershey PA, USA: Information Science Reference.

San Martín, H., \& Rodríguez Del Bosque, I. A. R. (2008). Exploring the cognitive-affective nature of destination image and the role of psychological factors in its formation. Tourism Management, 29(2), 263-277.

Sarstedt, M., Henseler, J., \& Ringle, C. M. (2011). Multigroup analysis in partial least squares (PLS) path modeling: Alternative methods and empirical results. In M. Sarstedt, M. Schwaiger, C. R. Taylor, (Eds.), Measurement and Research Methods in International Marketing (Advances in International Marketing, Volume 22), (pp. 195218). Bingley, UK: Emerald Group Publishing Limited.

Segittur (2014). Impacto de la innovación y las nuevas tecnologías en los hábitos del nuevo turista en España.

http://www.segittur.es/opencms/export/sites/segitur/.content/galerias/descargas/docum entos/_Impacto-de-la-Innovacin-y-las-nuevas-tecnologas-en-los-hbitos-del-tu-.pdf (accessed 8/7/16)

Sheldon, P. J. (1997). Tourism information technology. Oxford: CAB International.

Smith, A. N., Fischer, E., \& Chen, Y. (2012). How Does Brand-related User-generated Content Differ across YouTube, Facebook, and Twitter? Journal of Interactive Marketing, 26(2), 102-113.

Smith, W. W., Li, X. R., Pan, B., Witte, M., \& Doherty, S. T. (2015). Tracking destination image across the trip experience with smartphone technology. Tourism Management, $48,113-122$.

Stepchenkova, S., \& Li. X., (2014). Destination image: Do top-of-mind associations say it all? Annals of Tourism Research, 45, 46-62.

Stepchenkova, S., \& Zhan, F. (2013). Visual destination images of Peru: Comparative content analysis of DMO and user-generated photography. Tourism Management, 36, 590601.

Stepchenkova, S., Kim, H., \& Kirilenko, A. (2015). Cultural differences in pictorial destination images Russia through the camera lenses of American and Korean tourists. Journal of Travel Research, 54(6), 758-773.

Stone, M. (1974). Cross-validatory choice and assessment of statistical predictions. Journal of the Royal Statistical Society. Series B (Methodological), 36(2), 111-147.

Tan, W. K., \& Wu, C. E. (2016). An investigation of the relationships among destination familiarity, destination image and future visit intention. Journal of Destination Marketing and Management, 5(3), 214-226.

Tasci, A. D., \& Gartner, W. C. (2007). Destination image and its functional relationships. Journal of Travel Research, 45(4), 413-425.

Tenenhaus, M., Vinzi, V. E., Chatelin, Y. M., \& Lauro, C. (2005). PLS path modeling. Computational Statistics \& Data Analysis, 48(1), 159-205.

Tigre Moura, F., Gnoth, J., \& Deans, K. R. (2015). Localizing Cultural Values on Tourism Destination Websites: The Effects on Users' Willingness to Travel and Destination Image. Journal of Travel Research, 54(4), 528-542. 
Tseng, C., Wu, B., Morrison, A. M., Zhang, J., \& Chen, Y. C. (2015). Travel blogs on China as a destination image formation agent: A qualitative analysis using Leximancer. Tourism Management, 46, 347-358.

Van Der Veen, R., \& Song, H. (2014). Impact of the perceived image of celebrity endorsers on tourists' intentions to visit. Journal of Travel Research, 53(2), 211-224.

Walmsley, D. J., \& Young, M. (1998). Evaluative images and tourism: The use of personal constructs to describe the structure of destination images. Journal of Travel Research, 36(3), 65-69.

Wang, Y., \& Fesenmaier, D. (2003). Assessing motivation of contribution in online communities: an empirical investigation of an online travel community. Electronic Markets, 13(1), 33-45.

Woodside, A.G., Ramos-Mir, V., \& Duque, M. (2011). Tourism’s destination dominance and marketing website usefulness. International Journal of Contemporary Hospitality Management, 23(4), 552-564.

Xiang, Z., \& Gretzel, U. (2010). Role of social media in online travel information search. Tourism Management, 31(2), 179-188.

Xiong, J., Hashim, N. H., \& Murphy J. (2015). Multisensory image as a component of destination image. Tourism Management Perspectives, 14, 34-41.

Ye, Q., Zhang, Z., \& Law, R. (2009). Sentiment classification of online reviews to travel destinations by supervised machine learning approaches. Expert Systems with Applications, 36(3), 6527-6535.

Zaichkowsky, J. L. (1985). Measuring the involvement construct. Journal of Consumer Research, 12, 341-352.

Zhang, H., Fu, X., Cai, L. A., \& Lu, L. (2014). Destination image and tourist loyalty: A metaanalysis. Tourism Management, 40, 213-223. 